\title{
Internacjonaliści i miejscowi - międzynarodowa współpraca badawcza w Polsce na mikropoziomie indywidualnych naukowców
}

STRESZCZENIE: W tekście porównano „internacjonalistów” i „miejscowych” (czyli badaczy umiędzynarodowionych i lokalnych w badaniach naukowych) - pierwsi to naukowcy zaangażowani w międzynarodową współpracę badawczą, a drudzy w nią niezaangażowani. Jako wyraźnie zdefiniowana grupa polskich naukowców $(51,4 \%)$, internacjonaliści stanowią ich odrębny typ. Dehermetyzacja polskiego systemu nauki stawia miejscowych w radykalnie trudniejszej sytuacji. Procesy nazwane przez nas „skumulowaną przewagą z racji umiędzynarodowienia” i „skumulowaną stratą z racji braku umiędzynarodowienia" zachodzą jednocześnie, dzieląc środowisko naukowe pod względem prestiżu, uznania i dostępu do konkurencyjnego finansowania badań. Umiędzynarodowienie w badaniach naukowych jest potężną siłą rozwarstwiającą nie tylko instytucje (powodującą ich pionowe zróżnicowanie), ale także ich wydziały (doprowadzając do segmentacji poziomej). Wyłaniają się zatem wysoce umiędzynarodowione instytucje, wydziały, grupy badawcze i indywidualni naukowcy. Przetestowano dziewięć hipotez roboczych dotyczących płci, wieku i stanowiska, współpracy krajowej, poziomu produktywności badawczej, rozkładu czasu pracy, orientacji na role akademickie, predyktorów bycia internacjonalistą i typu produktywności badawczej. Internacjonaliści to głównie mężczyźni i naukowcy starsi, mający dłuższe doświadczenie akademickie i wyższe stopnie naukowe. We wszystkich klastrach dyscyplin akademickich internacjonaliści generują ponad 90\% publikacji powstałych w ramach współpracy międzynarodowej: brak współpracy międzynarodowej w praktyce oznacza brak międzynarodowych publikacji współautorskich. Internacjonaliści są znacznie bardziej produktywni jeśli chodzi o międzynarodowe publikacje współautorskie: reprezentują $2320 \%$ produktywności miejscowych w przypadku artykułów recenzowanych i 1600\% w przypadku ich ekwiwalentów. Internacjonaliści poświęcają mniej czasu na działalność dydaktyczną, więcej na badania i więcej na obowiązki administracyjne. W Polsce większość kobiet naukowców stanowią miejscowi (55\%), a większość mężczyzn - internacjonaliści (56\%). W związku z tym awans kobiet na drabinie akademickiej opartej o osiągnięcia czysto naukowe będzie z czasem prawdopodobnie dłuższy, a dostęp do coraz bardziej konkurencyjnych funduszy indywidualnych na badania - coraz bardziej utrudniony. Nasze analizy wielowymiarowe (regresja logistyczna) zidentyfikowały nowe predyktory zaangażowania w międzynarodową współpracę badawczą. Wyniki analiz przeprowadzonych w oparciu o rozległe badanie ankietowe ( $\mathrm{n}=3704$ zwróconych kwestionariuszy) prowadzą do wniosków dotyczących kariery akademickiej, wzorców produktywności i umiędzynarodowienia badań naukowych. 
SŁOWA KLUCZOWE: współpraca naukowa, kariera akademicka, wzorce produktywności naukowej, umiędzynarodowienie badań

\section{Wprowadzenie}

Podstawowy podział wprowadzany w tym artykule to podział na „internacjonalistów” i „miejscowych”: pierwsi to naukowcy zaangażowani w międzynarodową współpracę badawczą, a drudzy w nią niezaangażowani. Te dwa odmienne typy kadry naukowej konkurują o prestiż akademicki (Wagner i Leydesdorff 2005), finansowanie badań (Jeong, Choi i Kim 2014) oraz uznanie w nauce (Merton 1973). Podczas gdy miejscowi wytwarzają wiedzę na potrzeby krajowych rynków badawczych i krajowej publiczności naukowej (Ziman 1991), internacjonaliści wytwarzają ją dla międzynarodowych (lub lokalnych i międzynarodowych) rynków i odbiorców. Ponieważ systemy nagradzania w nauce funkcjonują różnie w różnych krajach i dyscyplinach akademickich, dążenie do międzynarodowego uznania jest mniej lub bardziej „konieczne” (Kyvik i Larsen 1997: 260) w zależności od kraju i dyscypliny. W Polsce tradycyjnie w ostatnich trzech dekadach dążenie to nie było „konieczne”, a miejscowi w wielu dziedzinach nie funkcjonowali na gorszych warunkach niż internacjonaliści. Dehermetyzacja polskiego systemu nauki (Kwiek 2017), wprowadzająca zachodnie reguły oceny indywidualnych i instytucjonalnych osiągnięć naukowych, stopniowo wprowadzana od dekady i wzmacniana w Ustawie 2.0, a zwłaszcza nowej ewaluacji osiągnięć naukowych, stawia miejscowych w radykalnie trudniejszej sytuacji - a ich skupiska instytucjonalne (wydziały i uczelnie) stopniowo odcina od możliwości uprawiania nauki.

Dla intensywności podejmowanej współpracy międzynarodowej mają znaczenie dyscyplina akademicka, zatrudniająca instytucja i jej typ, dostępne środki na badania, dominujące wzorce publikacyjne, wymagania awansowe oraz krajowa struktura nagradzania w nauce. Jednak decyzja o umiędzynarodowieniu jest ostatecznie osobista, a pojęcia takie jak „samoorganizacja” (Wagner i Leydesdorff 2005: 1610; Melin 2000: 39; Wagner 2018: 84) i „współpraca nieformalna” (tj. prowadzona poza formalnymi porozumieniami) (Georghiou 1998: 612) są szczególnie istotne $\mathrm{w}$ badaniu poziomu umiędzynarodowienia nauki. $\mathrm{W}$ ramach globalnej sieci wiedzy motywacja do umiędzynarodowienia pochodzi od samych naukowców, a „więzi polityczne czy prestiż narodowy nie motywują sojuszy badaczy" (Wagner 2018: viii). Umiędzynarodowienie kadry w badaniach jest w sposób nieproporcjonalny kształtowane przez głęboko zakorzenione indywidualne wartości i upodobania (Finkelstein, Walker i Chen 2013). Naukowcy walczą o uznanie innych naukowców (Merton 1973; Cole i Cole 1973; Zuckerman 1970), ale różnią się między sobą skłonnościami do prowadzenia współpracy międzynarodowej: „im bardziej elitarny naukowiec, 
tym bardziej prawdopodobne jest, że będzie aktywnym członkiem globalnego niewidzialnego kolegium" - to znaczy, że będzie współpracował z kolegami z innych krajów (Wagner 2008: 15; Kwiek 2016a).

Wcześniejsze badania pokazują, że odsetek internacjonalistów wśród polskich naukowców jest znacznie niższy od średniej zachodnioeuropejskiej, a ich rola w produkcji wiedzy naukowej w Polsce jest znacznie większa (Kwiek 2015a). W Europie Polska należy do krajów o najniższym odsetku internacjonalistów. W badaniu przeprowadzonym w jedenastu krajach średni odsetek internacjonalistów wśród europejskich naukowców zatrudnionych na pełen etat w sektorze uniwersyteckim wyniósł $63,8 \%$ (Kwiek 2018b), a w Polsce internacjonaliści stanowią zaledwie 51,4\% wszystkich naukowców. Najniższy poziom umiędzynarodowienia badań w krajach Unii Europejskiej w 2018 roku mierzony według wskaźnika publikacji pisanych we współautorstwie międzynarodowym (35,8\% na podstawie danych Scopusa) ma wiele przyczyn, ale, najogólniej rzecz biorąc, wiąże się on z systematyczną „deinstytucjonalizacją" misji badawczej na polskich uczelniach, trwającą do około 2010 roku, a następnie jej powolną „reinstytucjonalizacją” (Kwiek 2012) wspieraną przez dwie fale reform szkolnictwa wyższego w ostatniej dekadzie (zob. przeglądy polskich systemów szkolnictwa wyższego i nauki w: Antonowicz 2016; Antonowicz, Kwiek i Westerheijden 2017; Dakowska 2015; Urbanek 2018; Bieliński i Tomczyńska 2018 oraz Ostrowicka i Stankiewicz 2018). Celem obecnych reform - z nowymi formułami finansowania badań, nową ewaluacją osiągnięć naukowych oraz wyborem dziesięciu „uczelni badawczych” w ramach „inicjatywy doskonałości” - jest zwiększenie międzynarodowej widzialności polskiej nauki. W praktyce kierunek zmian jest czytelny: więcej publikacji w najlepszych międzynarodowych czasopismach i więcej publikacji we współautorstwie międzynarodowym.

Niektórzy naukowcy są wyraźnie bardziej umiędzynarodowieni niż inni, a rozróżnienie to przenika polską naukę. Procesy określane tutaj mianem procesów „skumulowanej przewagi z racji umiędzynarodowienia” i „skumulowanej straty z racji braku umiędzynarodowienia" w polskiej nauce dzielą nie tylko instytucje (pogłębiając zróżnicowanie pionowe), ale także wewnątrz instytucji dzielą ich wydziały (prowadząc do segmentacji poziomej). Istnieją zatem wysoce umiędzynarodowione instytucje, wydziały, grupy badawcze i indywidualni naukowcy - oraz ich słabo umiędzynarodowione odpowiedniki. Dla internacjonalistów grupą odniesienia jest międzynarodowe środowisko akademickie, podczas gdy miejscowi publikują głównie na potrzeby krajowego środowiska akademickiego. Umiędzynarodowienie odgrywa coraz bardziej stratyfikującą rolę w ramach profesji akademickiej, ponieważ współpraca międzynarodowa oznacza zwykle wyższe wskaźniki publikacji (i wyższe wskaźniki cytowań); ci, którzy nie współpracują ze sobą na poziomie międzynarodowym, coraz częściej tracą na dostępie do zasobów i na prestiżu (oryginalny termin „skumulowana strata” accumulative disadvantage - był używany w: Cole i Cole 1973: 146). 
Niniejsze studium stawia szereg pytań badawczych: Jakie cechy odróżniają internacjonalistów od miejscowych? Co wyróżnia internacjonalistów pod względem tego, kim są, jak pracują lub co myślą o swojej pracy naukowej? Czy są bardziej produktywni? Jaki jest ich rozkład według dziedziny nauki, stanowiska, grupy wiekowej i płci? Czy częściej współpracują naukowo również w kraju? Jaki jest ich przeciętny rozkład czasu pracy i ukierunkowanie na rolę badawczą? Jakie czynniki indywidualne i instytucjonalne kształtują zaangażowanie w międzynarodową współpracę badawczą? Krótko mówiąc, czy internacjonaliści to jakiś odmienny typ naukowca?

Artykuł ma następującą strukturę: poniżej przedstawiamy ramy teoretyczne pracy, a następnie dane i metody. Część poświęcona wynikom zawiera ogólny opis internacjonalistów, wzorców indywidualnej produktywności naukowej i wzorców współpracy międzynarodowej, wzorców indywidualnej produktywności według typu publikacji, dwuwymiarową analizę rozkładu czasu pracy i roli dydaktycznej i naukowej oraz wielowymiarowy model regresji logistycznej. Model regresji logistycznej składa się z dwóch części; w ramach podejścia modelowego (I) badamy predyktory współpracy naukowej z kolegami z zagranicy, a podejścia modelowego (II) - wpływ różnych aspektów umiędzynarodowienia na produktywność naukową. Artykuł zamyka podsumowanie wyników, dyskusja i wnioski.

\section{Podstawy teoretyczne \\ 2.1. Międzynarodowa współpraca badawcza a struktury nagród w nauce}

Alvin Gouldner (1957) wprowadził rozróżnienie na naukowców, którzy są mniej zorientowani na badania i bardziej lojalni wobec zatrudniających ich organizacji (locals, czyli miejscowi) i naukowców, którzy są mniej lojalni wobec swojej organizacji i bardziej zorientowani na badania (cosmopolitans, czyli kosmopolici). Czyste typy idealne Gouldnera zostały z czasem przeformułowane zarówno w badaniach organizacji, jak i w badaniach szkolnictwa wyższego (zob. Glaser 1963; Abrahamson 1965; Rhoades et al. 2008; Smeby i Gornitzka 2008). W socjologii nauki Roberta K. Mertona (Merton 1973: 374) wybitni naukowcy są bardziej skłonni do bycia „kosmopolitami” zorientowanymi na ponadnarodowe środowiska naukowe, podczas gdy „miejscowi” są zazwyczaj nastawieni „przede wszystkim na swoich bezpośrednich współpracowników”, czyli lokalnych kolegów. Jednak rozróżnienie to nie odnosiło się pierwotnie do umiędzynarodowienia w nauce, lecz do ról organizacyjnych oraz tożsamości i norm zawodowych, a w centrum uwagi znajdowała się koncepcja międzyinstytucjonalnej mobilności.

Gouldner przeciwstawiał naukowców niemobilnych i zorientowanych na instytucje (lojalnych wobec wewnętrznych grup odniesienia) oraz naukowców mobilnych, kosmopolitycznych, ukierunkowanych na karierę naukową (i zarazem lojalnych wobec zewnętrznych grup odniesienia). Według Gouldnera profesjonaliści identyfikują się ze swoją grupą odniesienia i odwołują się do niej, oceniając własne osiągnięcia. 
Pod tym względem kosmopolici i miejscowi znacznie różnią się między sobą jeżeli chodzi o stosunek do badań, źródła naukowego uznania i akademickie ścieżki kariery (Wagner i Leydesdorff 2005).

W miarę jak systemy zachęt i nagród w europejskiej nauce ewoluują w kierunku większej orientacji na wyniki (Kyvik i Aksnes 2015; Kwiek 2019), poszczególni naukowcy znajdują się pod coraz większą presją współpracy i współpublikowania na arenie międzynarodowej, czyli stawania się ,internacjonalistami” w badaniach. Współpraca rośnie na poziomie autorów, instytucji i krajów (Gazni, Sugimoto i Didegah 2012), ponieważ finansowanie oparte na wynikach i świadomość znaczenia międzynarodowych rankingów akademickich opartych na danych dotyczących badań oznacza, że publikacje naukowe są ściśle powiązane z finansowaniem instytucjonalnym i wydziałowym. Mertonowska zasada pierwszeństwa odkrycia wskazuje, że międzynarodowa współpraca badawcza jest napędzana głównie przez struktury nagród w wysoce konkurencyjnych systemach naukowych, zwłaszcza w naukach twardych (Kyvik i Larsen 1997). Jak przekonują Wagner i Leydesdorff (2005: 1616), „widoczni i produktywni naukowcy, zdolni do dokonywania wyborów, pracują z tymi, którzy mają większe szanse na zwiększenie ich produktywności i wiarygodności naukowej”. Według nich „wiele indywidualnych wyborów naukowców dotyczących współpracy może być motywowanych przez struktury nagród w ramach nauki, gdzie współautorzy, cytowania i inne formy uznania zawodowego prowadzą do dodatkowych prac i uzyskania renomy w ramach spirali sukcesu" (Wagner i Leydesdorff 2005: 1616).

Nauka z jej masową międzynarodową współpracą badawczą może być postrzegana jako powstający, samoorganizujący się, sieciowy system, w którym wybór partnerów i środowiska badawczego często zależy od samych naukowców (Wagner 2018). W przypadku bardziej spontanicznej czy też oddolnej współpracy liczy się „,indywidualny interes naukowców poszukujących zasobów i renomy" (Wagner i Leydesdorff 2005: 1616). Najczęściej współpraca naukowa rozpoczyna się od spotkań twarzą w twarz, zwłaszcza na konferencjach (Melin 2000). W ramach zmieniających się struktur nagradzania, wyposażeni w nowe możliwości oferowane przez technologie informacyjno-komunikacyjne, poszczególni naukowcy coraz częściej współpracują ze sobą na arenie międzynarodowej; coraz częściej utrzymują ze sobą kontakty, które można opisywać za pomocą procesów „preferencyjnego przywiązania” - konkretni naukowcy są wybierani do coraz bardziej elitarnego kręgu nauki (Wagner 2018: x). Wszechobecność internacjonalistów w nauce zmienia sposób jej postrzegania, a brak współpracy staje się coraz rzadszym zjawiskiem, nawet w tradycyjnie bardziej nastawionej na samodzielne publikowanie humanistyce. Polska, z najniższym w Europie odsetkiem międzynarodowych publikacji współautorskich (Scopus 2020) i jednym z najniższych w Europie odsetków naukowców deklarujących współpracę międzynarodową, jest niezwykle ciekawym przypadkiem. 


\subsection{Badania ankietowe i badania bibliometryczne}

Nasze hipotezy badawcze zostały sformułowane w oparciu o badania bibliometryczne i badania ankietowe dotyczące międzynarodowej współpracy badawczej. O ile $\mathrm{w}$ dotychczasowych badaniach nie wykorzystywano dwóch zestawionych ze sobą prototypowych postaci badaczy internacjonalistów i badaczy miejscowych (w badaniach naukowych), o tyle obszerna literatura dotycząca międzynarodowej współpracy badawczej odegrała zasadniczą rolę w opracowaniu tych hipotez (podobne badania prowadziliśmy w Kwiek 2015, gdzie zdefiniowano i omówiono internacjonalistów i badaczy miejscowych w 11 systemach europejskich. Ponadto Rostan i in. 2014 oraz Cummings i Sethi 2014 analizowali naukowców współpracujących i nie współpracujących z zagranicą, a Cummings i Finkelstein 2012, porównywali mniejszość „internacjonalistów” z ich „wyizolowanymi kolegami” w USA; wszystkie cztery badania opierały się na danych ankietowych i zestawiały naukowców zaangażowanych i niezaangażowanych we współpracę międzynarodową w badaniach). W szczególności przydatne okazały się badania prowadzone w ramach dwóch dużych międzynarodowych projektów porównawczych dotyczących zmieniającej się profesji akademickiej (badania CAP i EUROAC, zob. podrozdział na temat zbioru danych poniżej) i publikowane sukcesywnie w ciągu ostatnich dziesięciu lat. Natomiast większość badań bibliometrycznych odnosi się do międzynarodowej współpracy badawczej definiowanej jako tworzenie publikacji przez współautorów międzynarodowych, a nie prowadzenie badań z międzynarodowymi współpracownikami, jak w naszym przypadku. Jednak badania ankietowe i bibliometryczne są ze sobą ściśle powiązane, analizują ściśle powiązane ze sobą zjawiska, a zatem pomogły rozwinąć nasze hipotezy.

\subsection{Międzynarodowa współpraca badawcza a płeć}

Istnieje kilka studiów opartych na badaniach ankietowych koncentrujących się na międzynarodowej współpracy badawczej i płci (oraz wiele badań dotyczących współpracy badawczej w ogóle i płci), w większości wskazujących, że bycie kobietą naukowcem jest negatywnym predyktorem międzynarodowej współpracy badawczej (Rostan, Ceravolo i Metcalfe 2014; Vabø, Padilla-Gonzales, Waagene i Naess 2014; Kwiek 2018b). Jak podsumowano profil naukowca współpracującego na arenie międzynarodowej w globalnym badaniu ankietowym, „prototypową postacią w międzynarodowej współpracy badawczej jest mężczyzna mający około 55 lat, pracujący jako profesor w dziedzinie nauk przyrodniczych na uniwersytecie w małym, nieazjatyckim i nieanglojęzycznym kraju o rozwiniętej gospodarce. Mężczyzna ten pochodzi z rodziny dobrze wykształconej i uzyskał stopień naukowy doktora za granicą" (Rostan i in. 2014: 130). W studiach dotyczących płci i współpracy międzynarodowej (Vabø i in. 2014: 191), niezależnie od intensywności współpracy międzynarodowej w badaniach w każdym z badanych regionów (Azja, Europa, Ameryka Łacińska, a także RPA, 
Kanada, Australia i USA), kobiety naukowcy deklarują niższy poziom współpracy międzynarodowej w badaniach niż mężczyźni; gdy jednak dane zostają zdezagregowane według stanowisk akademickich, znaczenie nierówności między płciami w niektórych państwach (takich jak USA, Kanada, RPA i Australia) zanika wśród młodszych naukowców. Podczas gdy mężczyźni naukowcy na ogół są bardziej zaangażowani w międzynarodową współpracę badawczą, kobiety są bardziej zaangażowane w działania międzynarodowe w swoich uczelniach, na przykład w prowadzenie zajęć w języku obcym (Vabø i in. 2014: 202). Bycie mężczyzną znacznie zwiększa szanse zaangażowania się na międzynarodową współpracę badawczą w porównaniu z byciem kobietą (o 69\%, dla 11 krajów europejskich, jak pokazaliśmy w Kwiek 2018b).

Międzynarodowa współpraca badawcza napotyka na liczne bariery, ale kobiety inżynierowie badane przez Fox i współpracowników (Fox, Realff, Rueda i Morn 2017: 1304) wskazują na dwie zewnętrzne bariery umiędzynarodowienia: finansowanie i znajdowanie współpracowników, przy czym problemy osobiste/rodzinne postrzegane są jako znacznie mniej istotne bariery dla nich samych niż dla innych. Nierówny dostęp do międzynarodowej współpracy badawczej, analizowany ostatnio za pomocą koncepcji „szklanych barier”, jest uważany za formę nierówności związanych z płcią: „podczas gdy kobiety czasami pokonują te bariery, to wymaga to dodatkowego wysilku" w porównaniu z mężczyznami (Uhly i in. 2015: 3; na temat globalizacji nauki jako procesu, który utrwala nierówności ze względu na płeć i pociąga za sobą niekorzystne skutki w międzynarodowej współpracy badawczej kobiet naukowców, zob. Zippel 2017; argumenty przemawiające za umiędzynarodowieniem, a zwłaszcza za mobilnością międzynarodową, jako „pośrednią dyskryminacją” kobiet naukowców, zob. Ackers 2008).

Drugi kierunek badań, czyli zróżnicowanie pod względem płci w międzynarodowej współpracy badawczej z perspektywy bibliometrycznej, został przeanalizowany szczególnie w dwóch krajach: w Norwegii i we Włoszech, z ogólnymi wnioskami stwierdzającymi, że skłonność do międzynarodowej współpracy badawczej jest albo podobna w przypadku mężczyzn i kobiet naukowców (Norwegia), albo wyższa w przypadku kobiet naukowców w odniesieniu do całej populacji, ale podobna w przypadku mężczyzn i kobiet osiągających najlepsze wyniki (top scientists, Włochy). Luka w badaniach nad różnicami dotyczącymi płci w ogólnej współpracy badawczej, a w szczególności w międzynarodowej współpracy badawczej, była sukcesywnie eliminowana w badaniach, w których poszczególni naukowcy są traktowani jako podstawowa jednostka analizy - zarówno w przypadku całych populacji, jak i najlepszych naukowców na poziomie krajowym. Abramo, D’Angelo i Murgia (2013) pokazują, że w przypadku wszystkich włoskich naukowców kobiety naukowcy wykazują większą skłonność do współpracy w dwóch formach (współpraca wewnętrzna i zewnętrzna współpraca krajowa), ale mniejszą skłonność w trzeciej formie, zewnętrznej współpracy międzynarodowej. Ich podejście metodologiczne nie prowadzi do wyników 
zniekształconych przez wartości odstające, tj. przypadki wysoko produktywnych i wysoko umiędzynarodowionych naukowców, których obszerne portfolio publikacji zniekształca wartość wskaźników zagregowanych (Abramo i in. 2013: 820). Podobnie Aksnes, Piro i Rørstad (2019), wykorzystując bibliograficzną bazę danych CRISTIN (Norweski Indeks Naukowy, obejmujący wszystkie recenzowane publikacje), badają różnice wynikające z płci w skłonności do międzynarodowej współpracy na czterech największych uniwersytetach, przy czym głównym czynnikiem decydującym jest dziedzina nauki. Jednostką ich analizy jest indywidualny naukowiec: wszyscy naukowcy liczą się w analizie w równym stopniu jako jedna jednostka, niezależnie od ich produktywności (Aksnes i in. 2019: 8), tak więc rola wartości odstających, obecnych w każdym systemie, jest ograniczona. Gdy analizuje się dane z Norwegii według dziedzin, stanowisk akademickich i produktywności publikacyjnej, różnice w skłonności norweskich naukowców do współpracy międzynarodowej są niewielkie i statystycznie nieistotne. Bibliometryczne analizy zachowań najlepszych naukowców w zakresie współpracy koncentrujące się na płci pokazują, że nie ma istotnych różnic w ogólnej skłonności do współpracy w podziale na płeć: w odróżnieniu od kobiet, które nie są najlepszymi naukowcami, najlepsze badaczki wykazują skłonność do angażowania się we współpracę międzynarodową na poziomie porównywalnym do mężczyzn (Abramo, D’Angelo i Di Costa 2019: 11).

\subsection{Międzynarodowa współpraca naukowa a wiek, pokolenia akademickie i stopnie naukowe}

Badania łączące wiek (jak również stopnie naukowe) i międzynarodową współpracę badawczą są nieliczne, a główną przeszkodą dla ich realizacji jest brak zbiorów danych łączących dane biograficzne z danymi dotyczącymi publikacji i cytowań na poziomie indywidualnym. Łączenie takich typów danych może odbywać się na poziomie poszczególnych instytucji; badania na dużą skalę na poziomie krajowym wymagają albo łączenia zbiorów danych przez autorów badań (tak jak we Włoszech, zob. Abramo, D’Angelo i Solazzi 2011; Abramo, D’Angelo i Murgia 2016 oraz prace prowadzone aktualnie przez nas w Polsce), albo obszernych zbiorów danych na poziomie krajowym (takich jak baza CRISTIN w Norwegii). Ponieważ postępujące starzenie się kadry akademickiej w Europie jest poważnym wyzwaniem, szczególnie przydatne stają się badania krajowych populacji naukowców oparte na danych. Do najważniejszych studiów zalicza się prace Abramo et al. (2016: 318), którzy badali wszystkich włoskich profesorów zwyczajnych, dochodząc do ogólnego wniosku, że wraz ze wzrostem wieku następuje wysoki spadek produktywności profesorów zwyczajnych; jednak profesorowie, którzy uzyskali tytuł profesora zwyczajnego w młodym wieku, utrzymują i zwiększają swoją produktywność w większym stopniu niż ich koledzy awansowani w późniejszym wieku (zob. prace Levin i Stephan 1989 
oraz Stephan i Levin 1992, które doprowadziły je do modelu produktywności naukowej motywowanej inwestycyjnie, w którym naukowcy stają się mniej produktywni w miarę starzenia się, zob. Levin i Stephan 1991; Kyvik 1990; Kyvik i Olsen 2008). Dopiero niedawno produktywność wszystkich naukowców została skontrastowana z produktywnością naukowców osiągających najlepsze wyniki pod kątem ich średniego wieku. Costas i współpracownicy (2010) w swoim badaniu bibliometrycznym naukowców hiszpańskiej Narodowej Rady ds. Badań Naukowych opartym na podejściu opartym na podziale na klasy (trójstronny podział na najwyższą, średnią i niską klasę produktywności) doszli do wniosku, że produktywność naukowców należących do najwyższej i średniej klasy produktywności rośnie wraz z wiekiem lub pozostaje stabilna wraz z wiekiem i spada jedynie w przypadku starszych naukowców; natomiast produktywność naukowców należących do najniższej klasy produktywności ma tendencję do spadku wraz z wiekiem (Costas, van Leeuwen i Bardons 2010: 1578). Bonaccorsi i Daraio (2003: 75) przeanalizowali wiek i produktywność naukowców z włoskiej Krajowej Rady ds. Badań Naukowych i doszli do wniosku, że produktywność maleje wraz z wiekiem, a średni wiek naukowców rośnie, co pociąga za sobą poważne konsekwencje dla krajowych systemów nauki.

Międzynarodową współpracę badawczą można badać według wieku lub według pokoleń akademickich. Przynależność do konkretnego pokolenia historycznego może mieć wpływ zarówno na produktywność indywidualną (Kwiek 2019), jak i na indywidualne możliwości zaangażowania się we współpracę międzynarodową (Rostan i in. 2014: 125), przy czym „pokolenia” oznaczają „pokolenia biograficzne” (wyrażone w wieku biologicznym), a „pokolenia statusowe” - etapy kariery (np. „młodszy” vs. „starszy” naukowiec, Jung, Kooij i Teichler 2014). Starszeństwo pod względem wieku i starszeństwo według etapów kariery zawodowej na ogół pokrywają się w większości krajów, w tym w Polsce (jak wyraźnie pokazuje stworzona i prowadzona przez nas zintegrowana baza biograficzna i publikacyjna 100000 polskich naukowców akademickich). Oparte na badaniach ankietowych międzypokoleniowe analizy profesji akademickiej mogą wykraczać poza porównywanie produktywności według szczebli kariery (jak w Jung 2014, według czterech szczebli kariery; oraz w Shin, Kim, Lim, Shim i Choi 2015, z trzema pokoleniami akademickimi); analizy międzypokoleniowe mogą również obejmować skłonność do współpracy międzynarodowej w badaniach. „Młodsze”, „średnie” $i$,starsze” pokolenia akademickie mogą być przedmiotem badań (jak w Santiago i in. 2015) i mogą one mieć różne wyobrażenia o tym, jaki powinien być odpowiedni poziom współpracy międzynarodowej (tak jak w Kyvik i Aksnes 2015 badano zmieniające się normy dotyczące właściwych zachowań akademickich jako główny czynnik wyjaśniający wzrost produktywności w Norwegii w ciągu ostatnich trzech dekad).

Wyjaśnienie większej skłonności do współpracy międzynarodowej w przypadku starszego pokolenia naukowców w badaniu 19 krajów jest proste: internacjonaliści mają 
„większą władzę, lepsze sieci kontaktów i dłuższe doświadczenie” (Jung i in. 2014: 214) lub mają więcej zasobów związanych z wyższymi stanowiskami w kategoriach „władzy, prestiżu, widoczności i pozycji naukowej” (Rostan 2015: 257). Młodsi naukowcy mogą również odnosić mniejsze sukcesy we współpracy międzynarodowej, ponieważ ten rodzaj współpracy jest droższy niż współpraca krajowa lub zwłaszcza współpraca wewnątrzinstytucjonalna. Wyjątkiem od tej reguły jest najstarsze pokolenie naukowców, jak pokazują Rostan i inni (2014: 129) dla tych samych 19 krajów świata. Jednak międzynarodowa współpraca badawcza staje się coraz bardziej powszechna wśród młodszych pokoleń, jak pokazują niedawne badania norweskie, na uniwersytetach badawczych jej udział wzrósł z 58\% w 1992 roku do 66\% w 2001 roku i 71\% w 2013 roku. Nie tylko młodsze pokolenia są bardziej umiędzynarodowione - prawie wszystkie pokolenia w miarę starzenia się coraz bardziej angażują się w międzynarodową współpracę badawczą (Kyvik i Aksnes 2015: 1448-1449). Jak pokazaliśmy (Kwiek 2019), międzypokoleniowe porównania europejskie wskazują, że największy odsetek naukowców współpracujących z międzynarodowymi partnerami badawczymi występuje wśród najstarszych pokoleń. W 11 badanych krajach udział naukowców współpracujących z międzynarodowymi partnerami naukowymi nigdy nie był najwyższy dla najmłodszej kohorty akademickiej. Nie jest to zaskakujące, ponieważ międzynarodowa współpraca badawcza potrzebuje czasu na rozwój, a także wymaga dostępu do finansowania (Jeong, Choi i Kim 2014).

Jednocześnie niektóre pokolenia wykazują większą skłonność do współpracy niż inne w miarę starzenia się, podobnie jak niektóre pokolenia są bardziej produktywne w miarę starzenia się, co jest wyraźnie związane ze zmieniającymi się w czasie warunkami na rynku pracy, z bardziej konkurencyjnymi okresami wchodzenia na rynek pracy w szkołach wyższych i mniej konkurencyjnymi, gdy miejsc pracy jest dużo, a możliwości zatrudnienia jest wiele. $\mathrm{W}$ bardziej konkurencyjnych czasach tylko młodzi naukowcy, którzy są bardziej produktywni i bardziej umiędzynarodowieni na samym początku swojej kariery zawodowej, mogą być zatrudniani w sektorze uniwersyteckim, w przeciwieństwie do mniej konkurencyjnych czasów, z szerokimi możliwościami zatrudnienia i łagodniejszymi procedurami selekcji (zob. zwłaszcza rolę czasu i miejsca w karierze naukowej w Stephan i Levin 1992 oraz wpływ „efektów kohortowych” na naukę w Stephan 2012). Różne obecnie zatrudnione generacje naukowców były również socjalizowane do akademii w ramach „różnych narracji na temat misji, celów i roli szkolnictwa wyższego w społeczeństwie" (Santiago i in. 2015: 1474) - narracje te w różnym stopniu podkreślały zarówno produktywność, jak i współpracę międzynarodową (oraz międzynarodową współpracę publikacyjną).

Niektóre pokolenia przodują we współpracy międzynarodowej na przestrzeni czasu i w miarę starzenia się, jak to wyraźnie pokazują Kyvik i Aksnes (2015: 1448) dla pokolenia najmłodszej kohorty wiekowej w latach 1989-1991, gdy starzeje się ona do lat 2000. Młodsi i starsi polscy naukowcy (zdefiniowani tu przez instrument badawczy 
i użytą próbę - wszyscy naukowcy wymienieni w ogólnopolskiej bazie danych, z której zaczerpnięto adresy e-mail) są podręcznikowym przykładem naukowców urodzonych w różnych epokach, pracujących z różnymi szansami zawodowymi i według różnych norm akademickich, z istotnym podziałem na wchodzących na akademicki rynek pracy przed 1989 i później (Kwiek 2017) oraz przed reformami z lat 2010 i później (Kwiek i Szadkowski 2018). Polscy naukowcy byli odporni na presję związaną z publikowaniem na arenie międzynarodowej, by osiągać postępy w karierze naukowej do czasu, gdy publikacje międzynarodowe stały się niezbędne w ramach ostatniej fali reform z lat 2018-2019. Publikacje międzynarodowe mają coraz większe znaczenie na indywidualnym i instytucjonalnym poziomie ewaluacji wyników badań naukowych i są silnie skorelowane z międzynarodową współpracą badawczą (Kwiek 2015).

Oprócz tradycyjnych podziałów między generacjami na młodsze i starsze pokolenia w międzynarodowej współpracy badawczej, w niektórych systemach akademickich istnieją również podziały związane z ważnymi wydarzeniami historycznymi. Polska przed upadkiem systemu komunistycznego w 1989 roku i po nim jest dobrym przykładem kraju, w którym do 1989 roku współpraca międzynarodowa ograniczała się w dużej mierze do bloku wschodniego. Innym przykładem jest Argentyna, badana za pomocą trójstronnego podziału swych naukowców na „naukowców ugruntowanych”, „naukowców epoki pośredniej” i „naukowców nowicjuszy”, przy czym te trzy grupy pokrywają się z kluczowymi okresami w dziejach Argentyny (zob. Marquina, Yuni i Ferreiro 2015: 1396). Jak wskazują Marquina i Jones (2015: 1349), różne pokolenia naukowców mogą „doświadczać i rozumieć pracę akademicką w zupełnie inny sposób”, dlatego pokoleniowe podejście do umiędzynarodowienia badań jest obiecującym kierunkiem przyszłych analiz.

\subsection{Międzynarodowa współpraca badawcza a dziedziny nauki}

Zróżnicowanie dziedzin nauki pod względem średniego poziomu umiędzynarodowienia zostało omówione w licznych opracowaniach (zob. Cummings i Finkelstein 2012: 103; Rostan i in. 2014; Rostan i in. 2014: 122-123; Vabø i in. 2014; Finkelstein i Sethi 2014, a ostatnio Aksnes i in. 2019), przy czym ogólny wniosek z badań jest taki, że dziedziny nauki są silnie skorelowane z wzorcami współpracy międzynarodowej. Stwierdzono, że naukowcy z dziedzin „twardych” są 2,3 razy bardziej skłonni do umiędzynarodowienia swoich badań niż ci z dziedzin „miękkich” (w modelu predykcyjnym z danymi z 19 krajów, zob. Finkelstein i Sethi 2014). Przynależność dyscyplinarna kształtuje orientację naukowców na działalność międzynarodową, a narodowość wpływa na ich motywację i możliwość zaangażowania się w nią (Finkelstein i Sethi 2014: 235). Również presja na międzynarodowe publikacje jest większa $\mathrm{w}$ dziedzinach twardych niż miękkich, przy czym nacisk na publikacje w ramach „odpowiednich kanałów naukowych” skutkuje bardziej intensywną współpracą międzynarodową w tych pierwszych dziedzinach (Kyvik i Aksnes 2015). Naukowcy z klastra nauk fizycznych i matematycznych są 
uważani za zdecydowanie najbardziej umiędzynarodowionych w badaniach prowadzonych w 11 systemach europejskich (76,2\%, czyli trzy czwarte z nich, współpracuje w badaniach międzynarodowych), a naukowcy z klastra nauk o charakterze zawodowym za najmniej umiędzynarodowionych (53,3\%, czyli około połowa, zob. Kwiek 2015: 347-348). Oprócz różnic w ramach krajowych i międzynarodowych społeczności dyscyplinarnych, presja współpracy różni się także w zależności od wydziału i instytucji (największa jest w uczelniach prowadzących intensywną działalność badawczą, a najmniejsza w instytucjach nastawionych na kształcenie) (Kwiek 2019).

\subsection{Międzynarodowa współpraca badawcza a produktywność}

Temat międzynarodowej współpracy badawczej (jak również międzynarodowych publikacji współautorskich) i produktywności badawczej był szeroko analizowany w ciągu ostatnich kilku dekad w badaniach ankietowych opartych na wywiadach i badaniach bibliometrycznych. Istotnym ograniczeniem danych ankietowych z całej rodziny artykułów CAP/EUROAC (łącznie 600 prac) jest fakt, że badania te nie są w stanie określić względnego wpływu międzynarodowej współpracy poza wymiernymi korzyściami w zakresie produktywności - ponieważ instrument badawczy nie zapewniał dostępu do nazw czasopism i cytowań (Rostan i in. 2014). W naszych badaniach wysoko produktywnych naukowców w 11 systemach europejskich (Kwiek 2016: 388-393) pokazaliśmy, że pod względem statystycznie istotnych pojedynczych zmiennych blok „umiędzynarodowienie i współpraca” pojawia się jako najważniejsza grupa zmiennych w przewidywaniu wysokiej produktywności badawczej: trzy zmienne („współpraca międzynarodowa”, „publikowanie w obcym kraju” i „badania o zasięgu lub orientacji międzynarodowej”) co najmniej podwajają szanse zostania wysoko produktywnym naukowcem, przy czym są oni definiowani jako naukowcy znajdujący się w górnych 10\% pod względem produktywności badawczej.

W szczególnym przypadku polskich wysoko produktywnych naukowców z dziedzin STEM współpraca międzynarodowa zwiększa szanse wejścia do tej klasy siedmiokrotnie - i okazuje się najważniejszą zmienną w modelu regresji logistycznej, wraz z „publikowaniem za granicą”; oba te czynniki są znacznie silniejszymi predyktorami niż dwa tradycyjne predyktory wysokiej produktywności: orientacja badawcza i czas poświęcony na badania (Kwiek 2018c: 443). Jak pokazano gdzie indziej, we wszystkich 11 badanych krajach i we wszystkich klastrach dziedzin nauki, międzynarodowa współpraca badawcza jest skorelowana ze znacznie większą liczbą publikacji (Kwiek 2015: 350; choć relacje między produktywnością a współpracą nie muszą być przyczynowe - bardziej produktywni naukowcy są z pewnością bardziej widoczni na arenie międzynarodowej - a zatem potencjalnie bardziej atrakcyjni jako partnerzy we współpracy międzynarodowej). Ogólny wniosek z badań włoskich naukowców jest taki, że zarówno produktywność badawcza, jak i przeciętna jakość 
dorobku, mają pozytywny wpływ na intensywność współpracy międzynarodowej. Zakres współpracy międzynarodowej jest pozytywnie skorelowany z produktywnością, a produktywność ma wpływ na intensywność współpracy międzynarodowej i średnią jakość publikacji (Abramo, D’Angelo i Solzazzi 2011: 642). Istnieją rozbieżne dowody na to, że silniej współpracujący naukowcy są bardziej produktywni, szczególnie przy użyciu frakcjonowanej metody liczenia publikacji (Abramo, D’Angelo i Murgia 2017), a wskaźniki współpracy różnią się znacznie w skali międzynarodowej i interdyscyplinarnej (Thelwall i Maflahi 2019; Fox, Realff, Rueda i Morn 2017). Ogólnie rzecz biorąc, bardziej produktywni naukowcy mają tendencję do prowadzenia szerszej współpracy z kolegami z zagranicy, podczas gdy najbardziej produktywni naukowcy są znacznie bardziej umiędzynarodowieni niż ich koledzy osiągający mniejszą produktywność (Kwiek 2019: 23-71). Chociaż produktywność jest bezpośrednio skorelowana z intensywnością i skłonnością do współpracy międzynarodowej, nie jest jasne, czy zależność ta działa również w drugą stronę (Abramo, D’Angelo i Solazzi 2011).

\subsection{Międzynarodowa współpraca badawcza, czas pracy i ukierunkowanie na rolę akademicką}

Podział czasu pracy i ukierunkowanie na rolę akademicką (kształcenie lub badania) w kontekście międzynarodowej współpracy badawczej, w przeciwieństwie do kontekstu produktywności badawczej, były rzadko analizowane. Oba zagadnienia wywodzą się z badań nad produktywnością, w których silne zaangażowanie w czas przeznaczony na badania (i niskie zaangażowanie w czas przeznaczony na kształcenie), silne ukierunkowanie na rolę badawczą (i słabe ukierunkowanie na rolę dydaktyczną) oraz międzynarodowy charakter badań (a nie ich charakter krajowy) są skorelowane z wysoką produktywnością badawczą (Cummings i Finkelstein 2012: 100-101; Kwiek 2019: 167-197). Oba zagadnienia były szeroko dyskutowane w ramach badań ankietowych - ponieważ badania częściowe, w tym ankietowe, w sposób spójny i definicyjnie zbieżny, a do tego stosunkowo tani (w porównaniu do np. badań pełnych lub tworzenia własnych repozytoriów) umożliwiają analizować takie zachowania akademickie i akademickie postawy. Jednak, zgodnie z naszą wiedzą, w żadnych publikacjach nie konfrontowano internacjonalistów z miejscowymi zgodnie z tymi dwoma kierunkami: wzorcami pracy i orientacją na rolę akademicką kształcenia/badania. W 19 badanych krajach prawdopodobieństwo umiędzynarodowienia badań było o połowę mniejsze w przypadku naukowców nastawionych przede wszystkim na kształcenie (Finkelstein i Sethi 2014: 253).

\subsection{Międzynarodowa i krajowa współpraca badawcza}

Związek między tymi dwoma typami współpracy, krajową i międzynarodową, był rzadko rozważany. Wzorce współpracy (krajowej i międzynarodowej) zmieniają się na poszczególnych etapach kariery, przy czym młodsi naukowcy deklarują wyższy 
poziom współpracy międzynarodowej przy prowadzeniu badań niż starsi naukowcy (Shin i in. 2014: 191). Zmienna „współpraca krajowa” okazuje się nieistotna statystycznie w analizie regresji logistycznej stworzonej w celu oszacowania wysokiej produktywności badawczej w żadnym kraju europejskim z wyjątkiem Wielkiej Brytanii (Kwiek 2016: 392), gdzie zwiększa ona ponad czterokrotnie szanse zostania naukowcem wysoce produktywnym. Można przyjąć, że współpraca krajowa słabnie wraz ze wzrostem współpracy międzynarodowej (co można określić jako „efekt wypierania”); alternatywą jest możliwość, że naukowcy silnie współpracujący w skali międzynarodowej mogą również silnie współpracować w skali krajowej (oraz instytucjonalnej). W badaniach bibliometrycznych korelacje te można mierzyć z pojedynczą osobą jako jednostką analizy, porównując naukowców z wysoce umiędzynarodowionymi portfolio publikacji (,,internacjonaliści”) i tych ze słabo umiędzynarodowionym portfolio publikacji („miejscowi”) według dziedzin akademickich i płci; w zależności od dostępności danych można analizować zarówno poziom instytucjonalny, jak i poziom krajowy.

\subsection{Międzynarodowa współpraca badawcza: predyktory indywidualne vs. instytucjonalne}

W pracach opartych na badaniach częściowych analizowano indywidualne i instytucjonalne predyktory wysokiego umiędzynarodowienia w badaniach oraz zależności między różnymi wymiarami umiędzynarodowienia a różnymi typami produktywności do analiz opartych na regresji logistycznej potrzebne są m.in. samodzielnie deklarowane dane dotyczące różnych typów działań związanych z umiędzynarodowieniem. Analizy danych wskazują, że naukowcy w instytucjach, w których poszczególni badacze dążą do umiędzynarodowienia, są bardziej skłonni być „internacjonalistami” niż naukowcy w instytucjach, w których to administracja ustanawia powiązania międzynarodowe (Finkelstein i Sethi 2014: 253). W naszym studium wysokiej produktywności badawczej ogólna siła determinująca predyktorów na poziomie indywidualnym była znacznie większa niż predyktorów na poziomie instytucjonalnym (Kwiek 2016: 392). Przykładem mogą być też liczne badania częściowe, w których wykorzystywano regresję logistyczną do badania międzynarodowej współpracy badawczej i wykorzystywano zarówno indywidualne, jak i instytucjonalne zmienne niezależne: na przykład Rostan, Ceravolo i Metcalfe 2014; Finkelstein i Sethi 2014; Cummings i Finkelstein 2012, przy czym ogólne wnioski wskazują, że indywidualne zmienne są znacznie ważniejsze w przewidywaniu międzynarodowej współpracy badawczej niż zmienne instytucjonalne.

\subsection{Hipotezy badawcze}

W ramach prowadzonych badań przetestowano dziewięć hipotez roboczych.

H1. Hipoteza dotycząca płci - internacjonaliści to częściej mężczyźni niż kobiety. 
H2. Hipoteza dotycząca wieku i stanowiska - internacjonaliści są zazwyczaj starsi i zajmują wyższe stanowiska.

H3. Hipoteza dotycząca rozkładu według dziedzin nauki - internacjonaliści wywodzą się częściej z dziedzin twardych niż miękkich.

H4. Hipoteza dotycząca współpracy krajowej - internacjonaliści współpracują w kraju częściej niż miejscowi.

H5. Hipoteza dotycząca poziomu produktywności badawczej - internacjonaliści są bardziej produktywni niż miejscowi.

H6. Hipoteza dotycząca rozkładu czasu pracy - internacjonaliści pracują dłużej i poświęcają więcej czasu na badania, mniej na kształcenie i więcej na pracę administracyjną.

H7. Hipoteza dotycząca orientacji na role akademickie - internacjonaliści są bardziej ukierunkowani na badania, a miejscowi na kształcenie.

H8. Hipoteza dotycząca predyktorów - indywidualne predyktory bycia internacjonalistą są ważniejsze niż predyktory instytucjonalne.

H9. Hipoteza dotycząca typu produktywności badawczej - różne wymiary umiędzynarodowienia są istotnie skorelowane z różnymi miarami produktywności.

\section{Dane i metody \\ 3.1. Definicja internacjonalistów}

Internacjonaliści są tutaj jasno zdefiniowani jako naukowcy, którzy współpracują w badaniach naukowych z kolegami z zagranicy. Współpraca taka może wskazywać na różne poziomy międzynarodowej mobilności i współautorstwa publikacji (od poziomu intensywnego do zerowego). Internacjonaliści są tutaj przeciwstawiani miejscowym definiowanym jako naukowcy, którzy nie współpracują w badaniach z kolegami z zagranicy. W badaniu ankietowym pytania dotyczące międzynarodowej współpracy naukowej zostały sformułowane w następujący sposób: „Jak scharakteryzowałby Pan(i) własną działalność badawczą w bieżącym (lub w poprzednim) roku akademickim? Czy w prowadzonych badaniach współpracuje Pan(i) z naukowcami z zagranicy?” (tak/ nie) (pytanie D1/4). W kwestionariuszu nie podano wyjaśnień ani wskazówek dotyczących rozumienia terminów „,współpracować”, „międzynarodowy” czy „działalność badawcza”.

\subsection{Dane}

Dane pochodzą z badania Academic Profession in Europe: Responses to Societal Challenges (EUROAC), która jest europejską wersją siostrzanego globalnego badania Changing Academic Profession (CAP) (zob. Carvalho 2017, aby zapoznać się z najnowszym przeglądem rodziny tekstów powstałych w ramach projektów CAP/ EUROAC; Marek Kwiek był kierownikiem polskiego zespołu badawczego finansowanego przez EUROCORES EuroHESC European Science Foundation). Ostateczny 
zestaw danych, datowany na 17 czerwca 2011 r., został stworzony przez René Kooija i Floriana Löwensteina z INCHER-Kassel. Uzyskana zwrotność w Polsce (11,22\%) była zbliżona do zwrotności uzyskanej w badaniach kadry akademickiej w kilku innych krajach w ciągu ostatniej dekady, w tym w Holandii (18\%) (de Weert i van der Kaap 2014: 121), Kanadzie (17\%) (Jones et al. 2014: 348), Wielkiej Brytanii (15\%) (Locke i Benion 2011: 178), Hongkongu (13\%) (Rostan i in. 2014: 25), Korei (13\%) (Shin i in. 2014: 183) oraz w Chorwacji, Austrii, Szwajcarii i Portugalii (10\% lub mniej) (Teichler i Höhle 2013: 8).

Naukowcy zostali zgrupowani w ośmiu klastrach dyscyplin, które najlepiej reprezentują obecną strukturę polskiej kadry akademickiej: nauki humanistyczne (HUM), nauki społeczne (SOC), nauki o życiu (LIFE), nauki fizyczne i matematyczne (PHYSMATH), nauki inżynieryjne i techniczne (ENGITECH), nauki rolnicze (AGRICULT), nauki medyczne i nauki o zdrowiu (MEDHEALTH) oraz inne dyscypliny (np. sztuki piękne).

Łączna liczba ważnych kwestionariuszy (z odpowiedziami na co najmniej 50\% pytań) wyniosła 3704. Ponieważ z analizy końcowej usunięto kwestionariusze naukowców z „innych” dyscyplin, kadrę zatrudnioną na stanowisku docenta, kadrę dydaktyczną oraz tych, którzy nie odpowiedzieli na pytanie o współpracę międzynarodową w badaniach, ostatecznie uwzględniono 2453 obserwacje z siedmiu głównych klastrów dyscyplin: 1172 internacjonalistów (51,4\%) i 1107 miejscowych (48,6\%).

Tabela 1. Rozkład liczebności próby

\begin{tabular}{|c|c|c|c|c|c|c|c|}
\hline Clusters & $\begin{array}{l}\text { All } \\
\text { (n) }\end{array}$ & $\begin{array}{c}\text { Research- } \\
\text {-involved } \\
\left(n_{\mathrm{RI}}\right)\end{array}$ & $\begin{array}{c}\% \text { Re- } \\
\text { search- } \\
\text {-involved }\end{array}$ & $\begin{array}{l}\text { Internation- } \\
\text { alists } \\
\left.\text { (INT) (n } \mathbf{n}_{\mathrm{I}}\right)\end{array}$ & $\begin{array}{c}\text { Locals } \\
(\text { LOC) } \\
\left(\mathbf{n}_{\mathrm{L}}\right)\end{array}$ & $\begin{array}{l}\text { International- } \\
\text { ists }(I N T) \% \\
\left(n_{I}\right):\left(n_{L}+n_{I}\right)\end{array}$ & $\begin{array}{c}\text { Locals } \\
(\mathrm{LOC}) \% \\
\left(\mathrm{n}_{\mathrm{L}}\right):\left(\mathrm{n}_{\mathrm{L}}+\mathrm{n}_{\mathrm{I}}\right)\end{array}$ \\
\hline HUM & 566 & 561 & 99,1 & 251 & 271 & 48,1 & 51,9 \\
\hline SOC & 263 & 257 & 97,9 & 86 & 151 & 36,3 & 63,7 \\
\hline PHYSMATH & 191 & 190 & 99,7 & 144 & 39 & 78,7 & 21,3 \\
\hline LIFE & 417 & 415 & 99,5 & 256 & 148 & 63,4 & 36,6 \\
\hline ENGITECH & 557 & 554 & 99,5 & 256 & 264 & 49,2 & 50,8 \\
\hline AGRICULT & 176 & 174 & 99,3 & 62 & 95 & 39,5 & 60,5 \\
\hline MEDHEALTH & 284 & 279 & 98,3 & 117 & 139 & 45,7 & 54,3 \\
\hline Total & 2453 & 2430 & 99,1 & 1172 & 1107 & 51,4 & 48,6 \\
\hline Soft combined & 829 & 818 & 98,7 & 337 & 422 & 44,4 & 55,6 \\
\hline $\begin{array}{l}\text { Hard com- } \\
\text { bined }\end{array}$ & 1624 & 1612 & 99,3 & 835 & 685 & 54,9 & 45,1 \\
\hline
\end{tabular}

Objaśnienie: internacjonaliści = naukowcy współpracujący na arenie międzynarodowej $\mathrm{w}$ badaniach (odpowiedź: tak). Uwzględniono jedynie naukowców zatrudnionych w pełnym wymiarze czasu pracy w sektorze uniwersyteckim i zaangażowanych zarówno w działalność dydaktyczną, jak i badawczą.

Wszystkie dane opisane w wersji angielskiej. (Obie uwagi dotyczą wszystkich wykresów i tabel). 


\subsection{Dobór do próby}

W badaniu zastosowano metodę reprezentacyjną, tj. do badania dobierano jednostki w sposób losowy, zgodnie ze schematem losowania warstwowego. Utworzono operat losowania w ujęciu dwóch zmiennych: płeć i stanowisko akademickie. W ramach każdej warstwy zastosowano losowanie proste. Operat losowania utworzono na podstawie ogólnokrajowej bazy danych wszystkich polskich naukowców (baza OPI - Ośrodka Przetwarzania Informacji).

W momencie przeprowadzania badania populacja docelowa liczyła 83015 naukowców zatrudnionych w pełnym wymiarze czasu pracy w sektorze publicznym $(43,8 \%$ kobiet i 56,2\% mężczyzn, w tym 17683 profesorów zwyczajnych i nadzwyczajnych (21,3\%), 36616 adiunktów (44,1\%), 10784 asystentów (13,0\%) oraz 15013 starszych wykładowców i wykładowców (18,1\%) (GUS 2011: 308-309). Naukowcy pracujący wyłącznie w sektorze prywatnym zostali wyłączeni z populacji, ponieważ sektor ten jest niemal w całości nastawiony na kształcenie.

Struktura próby była zbliżona do struktury populacji generalnej pod względem płci i stanowiska akademickiego i obejmowała 45,2\% kobiet naukowców i 54,8\% mężczyzn naukowców; 22,6\% profesorów zwyczajnych i nadzwyczajnych, 42,1\% adiunktów, 10,9\% asystentów oraz $24,4 \%$ starszych wykładowców i wykładowców. Nie wystąpił błąd próbkowania - prawdopodobieństwo wylosowania do próby dla wszystkich naukowców z populacji było jednakowe; żaden z członków populacji nie miał ograniczonych szans na włączenie do próby ani żadna grupa naukowców nie została systemowo wyłączona z operatu losowania (Bryman 2012: 187). Nie przeprowadzono analizy porównawczej między osobami, które odpowiedziały i nie odpowiedziały na prośbę o wypełnienie ankiety (Stoop 2012: 122) ze względu na dostępność danych i nie przeprowadzono dalszego badania osób, które nie odpowiedziały na ankietę, dlaczego nie wzięły w niej udziału. Założono, że mamy do czynienia z czysto losowym mechanizmem generowania odmów udziału w badaniu (MCAR - missing completely at random), a wagi wynikające ze schematu doboru do próby zostały skalibrowane w taki sposób, aby dostosować rozkład próby do znanych, prawdziwych rozkładów w ujęciu stanowiska akademickiego i płci. Z założenia tego wynika, że nie występuje błąd wynikający z odmów odpowiedzi w badaniu. Błąd ten występuje wtedy, kiedy niektóre grupy respondentów są mniej skłonne niż inne do wzięcia udziału w badaniu lub do udzielenia odpowiedzi na niektóre pytania badawcze (Hibberts et al 2012: 72; Groves 2006). Jednak korelacji pomiędzy skłonnością do udziału w badaniu a kluczowymi charakterystykami badania nie można było oszacować ze względu na brak dostępności do operatu losowania (Groves 2006: 670).

\subsection{Narzędzie badawcze i pomiar statystyczny}

Badanie zostało przeprowadzone przez Ośrodek Przetwarzania Informacji (OPI). Zaproszenia do udziału w badaniu internetowym, z unikalnym identyfikatorem, wysłano 
w czerwcu 2010 r. do 33 tys. naukowców, których adresy mailowe były dostępne. Zawęziło to populację docelową, co doprowadziło do pojawienia się niemożliwego do oszacowania błędu pokrycia. W okresie od 1 czerwca 2010 r. do 20 lipca 2010 r. wysłano drogą elektroniczną dwa przypomnienia. W zaproszeniu do badania zapewniono o pełnej anonimowości, a przypomnienia wysyłano wyłącznie do osób, które nie udzieliły odpowiedzi, przy użyciu przypisanych identyfikatorów. Kwestionariusz został przetestowany pilotażowo w maju 2010 r., po czym dokonano przeglądu formy, słownictwa i struktury poszczególnych elementów ankiety.

W konfrontacji internacjonalistów i miejscowych w prezentowanym artykule istnieje kompromis między korzyściami płynącymi z wykorzystania samodzielnie podawanych danych dotyczących liczby publikacji jako jedynej miary produktywności naukowej a korzyściami płynącymi z wykorzystania kombinacji liczby publikacji, cytowań, indeksu H i innych miar bibliometrycznych. Szczegółowe dane na poziomie indywidualnym - w tym dane dotyczące międzynarodowej współpracy naukowej i międzynarodowe dane dotyczące współautorstwa publikacji - zostały wykorzystane pomimo świadomości ich niedoskonałości.

Zastosowanie techniki badań ankietowych nasuwa istotny problem: błędne zgłaszanie między innymi danych dotyczących liczby i typów publikacji. Problem dotyczy głównie pytań wrażliwych, na które respondenci mogą wybrać nierzetelną odpowiedź „z powodu chęci zaprezentowania się w najlepszym świetle wobec ankietera lub uniknięcia potencjalnych reperkusji” (McNeeley 2012: 382). Zgłaszanie nadmiernej liczby społecznie pożądanych zachowań w środowisku akademickim (np. liczby publikacji) oraz zaniżanie społecznie niepożądanych zachowań (np. poziomu niepublikowania) jest problemem (de Vaus 1985), a pewien poziom błędów w odpowiedziach jest nieunikniony. Wydaje się jednak, że polscy naukowcy dosyć rzetelnie przedstawiali dane dotyczące liczby i typów publikacji; w oparciu o publicznie dostępne dane dotyczące produktywności na poziomie instytucjonalnym i na poziomie wydziałów według typu instytucjonalnego rozkłady odpowiedzi odpowiadały wnioskom z wcześniejszej literatury, co sugeruje, że respondenci nie postrzegali pytań zawartych w kwestionariuszu jako szczególnie wrażliwych. Na przykład średnie poziomy liczby indywidualnych publikacji odpowiadały średnim poziomom dla sześciu głównych typów instytucjonalnych, z najwyższym poziomem dla „uniwersytetów” i „uniwersytetów technicznych”, a najniższym dla „akademii”. Zaobserwowany wysoki odsetek osób niepublikujących i niepublikujących w języku angielskim sugeruje, że błąd pomiaru dla danych publikacyjnych nie był istotnym problemem.

\subsection{Ograniczenia metodologiczne}

Zaprezentowane analizy opierają się w dużej mierze na danych deklaratywnych. Wybraną miarą produktywności badawczej była liczba recenzowanych artykułów i ekwiwalentów 
artykułów recenzowanych opublikowanych w trzyletnim okresie referencyjnym. W różnym stopniu respondenci „mogą przedstawiać badaczowi nieprawdziwy obraz, na przykład odpowiadając na pytanie, jaka mogłaby być ich sytuacja, a nie jaka jest sytuacja rzeczywista" (Cohen i in. 2011: 404). Chociaż dane dotyczące publikacji zgłaszane samodzielnie nie są doskonałe, nie wydają się pociągać za sobą błędów nielosowych (tzn. błędy są przypadkowe) czy też systematycznych (co ma miejsce, gdy błędy wykazują tendencję do zmiany w jednym kierunku; zob. Spector 1981: 13). W narzędziu badawczym nie rozróżniano poziomu i prestiżu czasopism akademickich i nie było możliwości badania wzorców cytowań. Współczynniki wpływu czasopism i liczba cytowań autorów nie wchodzily w zakres tego badania z powodu niedostępności danych. W związku z anonimizacją danych, produktywność poszczególnych badaczy nie mogła być powiązana z poszczególnymi instytucjami - poza sześcioma głównymi typami instytucjonalnymi.

Aby wzmocnić zasadność analiz (zob. także Kwiek 2018c, 2019), oprócz artykulów recenzowanych (peer-reviewed articles, PRA) zastosowano trzy inne miary: ekwiwalenty artykułów recenzowanych (peer-reviewed article equivalents, PRAE), ekwiwalenty artykułów recenzowanych międzynarodowo współtautorskich (internationally collaborative peer-reviewed article equivalents, IC-PRAE) oraz ekwiwalenty artykułów recenzowanych w języku angielskim (English peer-reviewed article equivalents, ENG-PRAE). Oznacza to, że liczba publikacji została również przeliczona na ekwiwalenty artykułów. Miara PRAE jest obliczana jako suma ważona własnych artykułów opublikowanych w książkach lub czasopismach (wycenianych jako ekwiwalent 1 artykułu), książek pod redakcją (wycenianych jako ekwiwalenty 2 artykułów) i książek autorskich (wycenianych jako ekwiwalenty 5 artykułów) opublikowanych w ciągu trzyletniego okresu referencyjnego. Jest to zgodne z procedurą stosowaną w Piro et al. (2013: 309), Rørstad i Aksnes (2015: 319), Bentley (2015: 870) oraz Gorelova i Lovakov (2016: 11). W większości analiz opartych na badaniach ankietowych 4-6 artykułów odpowiada jednej pełnej monografii.

Podobnie jak Bentley (2015), do każdej obserwacji zastosowaliśmy udział recenzowanych publikacji podany przez respondenta. Zaletą zastosowania miary PRAE w badaniach przekrojowych jest to, że obejmuje ona różne publikacje, w tym książki autorskie i redagowane (które nadal stanowią jeden z głównych typów publikacji w Polsce w dziedzinie nauk społecznych i humanistycznych). Miara IC-PRAE bazuje na samodzielnie zgłoszonym udziale publikacji współtworzonych z kolegami z zagranicy, a miara ENG-PRAE opiera się na samodzielnie zgłoszonym udziale publikacji wydawanych w języku obcym, który jest w przeważającej mierze językiem angielskim (dla 87,1\% polskich naukowców). W związku z tym w tekście korzystamy z liczby publikacji naukowych oraz odsetka publikacji recenzowanych przez środowisko naukowe, publikacji powstałych w języku angielskim oraz publikacji wspóltworzonych z kolegami z zagranicy. 
Przedstawione poniżej analizy produktywności naukowej przeliczają liczbę publikacji na ekwiwalenty artykułów w celu bardziej sprawiedliwego zestawienia dziedzin akademickich, w których wzorce publikacyjne są różne (Kyvik i Aksnes 2015). Miara PRAE została wykorzystana w celu ułatwienia bardziej kompleksowego zbadania różnic we wzorcach publikacyjnych w różnych dziedzinach pomiędzy najbardziej produktywną kadrą (górne 10\%) i jej resztą (pozostałe 90\%); miary IC-PRAE i ENG-PRAE zostały wykorzystane do zbadania, jak te dwie grupy różnią się pod względem umiędzynarodowienia. Ekwiwalenty artykułów zostały wykorzystane do porównań obejmujących duże klastry dyscyplin. Podejście to jest zgodne z podejściem przyjętym w Ramsden (1994: 213), Guldbrandsen i Smeby (2005: 938), Kyvik i Aksnes (2015: 1441), Villanueva-Felez et al. (2013: 472), Piro et al. (2013: 309), Teichler et al. (2013: 146-147) i Arimoto (2011: 296). Ekwiwalenty artykułów wykorzystywano również w pracach w Scientometrics i Journal of Informetrics (np. Kyvik 1989: 206; Piro et al. 2016: 945; Bentley 2015: 870; Røstad i Aksnes 2015: 319). Zastosowanie miar PRA i PRAE odzwierciedla specyfikę polskiego systemu, który tradycyjnie wspierał publikację książek we wszystkich dziedzinach nauki.

\subsection{Inne ograniczenia}

Jednym z ograniczeń obecnego studium jest fakt, że narzędzie badawcze nie rozróżnia specyfiki krajów, lokalizacji (instytucji i wydziałów), intensywności (od wysokiej do niskiej) oraz sposobów kontaktu (np. bezpośredni/konferencja/e-mail) w ramach badanej międzynarodowej współpracy naukowej. Zamiast tego międzynarodowa współpraca naukowa jako kategoria behawioralna została zmierzona jako prosta odpowiedź „tak” lub „nie”, a zróżnicowane indywidualne postrzeganie umiędzynarodowienia w badaniach zostało zagregowane i uśrednione. Drugim ograniczeniem jest fakt, że polscy naukowcy nie mogli być porównywani między instytucjami na przykład studium nie oddaje różnic między naukowcami z prestiżowych instytucji (zwłaszcza instytucji flagowych, Uniwersytetu Warszawskiego i Uniwersytetu Jagiellońskiego; zob. Kwiek i Szadkowski 2018) a naukowcami z uczelni o niższym prestiżu i osiągnięciach naukowych. Kolejne ograniczenie dotyczy struktury zbioru danych; ponieważ nie można było dokonać rozróżnienia między publikacjami jedno- i wieloautorskimi, możliwe było jedynie stosowanie sumarycznych danych dla każdej obserwacji. To samo dotyczyło publikacji krajowych i międzynarodowych, wykraczających poza zastosowane przybliżenia („publikacje z naukowcami pracującymi zagranicą” i „publikacje w języku obcym”). I wreszcie, przekrojowy zestaw danych uniemożliwił dokonania porównania umiędzynarodowienia badań między pokoleniami akademickimi w czasie (a nie tylko w punkcie czasu). Pomimo tych ograniczeń, możliwe było przetestowanie zaproponowanych hipotez roboczych i wyciągnięcie wiążących wniosków. 


\section{Wyniki badań \\ 4.1. Internacjonaliści - przegląd ogólny}

H1. Hipoteza dotycząca plci - internacjonaliści to częściej mężczyźni niż kobiety.

Częstość wybranych cech demograficznych internacjonalistów przedstawia tabela 2. Nic dziwnego (w świetle istniejących wyników badań dotyczących roli płci w ramach międzynarodowej współpracy naukowej) (Ackers 2008; Fox et al. 2016; Abramo, D’Angelo i Murgia 2013), że mężczý́ni naukowcy są bardziej umiędzynarodowieni niż kobiety naukowcy; większość naukowców płci męskiej (56,0\%) jest internacjonalistami w porównaniu z 45,0\% kobiet. Różnice między płciami są uzależnione od dziedziny, a wyższy odsetek kobiet internacjonalistek występuje w twardych dziedzinach nauki. Różnice między płciami są statystycznie istotne i pociągają za sobą poważne konsekwencje w obszarze umiędzynarodowienia jako siły stratyfikującej w profesji akademickiej, a hipoteza 1 jest potwierdzona.

Tabela 2. Opis próby - częstość wybranych cech demograficznych

\begin{tabular}{|c|c|c|c|c|c|c|c|}
\hline & & \multirow{2}{*}{\multicolumn{2}{|c|}{$\begin{array}{c}\text { Internationalists } \\
\text { (INT) }\end{array}$}} & \multirow{2}{*}{\multicolumn{2}{|c|}{$\begin{array}{c}\begin{array}{c}\text { Locals } \\
\text { (LOC) }\end{array} \\
\mathrm{N}=\mathbf{1 , 0 9 0}\end{array}$}} & \multirow{2}{*}{\multicolumn{2}{|c|}{$\begin{array}{c}\text { Total } \\
\mathbf{N}=\mathbf{2 , 2 4 1}\end{array}$}} \\
\hline & & & & & & & \\
\hline & & $\mathbf{N}$ & $\%$ & $\mathbf{N}$ & $\%$ & $\mathbf{N}$ & $\%$ \\
\hline \multirow{2}{*}{ Gender } & Male & 722 & $56,0^{*}$ & 566 & 44 & 1288 & 57,5 \\
\hline & Female & 429 & 45 & 524 & $55,0^{*}$ & 953 & 42,5 \\
\hline \multirow{5}{*}{ Age group } & under 30 & 21 & 56,1 & 17 & 43,9 & 38 & 1,7 \\
\hline & 30 to 39 & 368 & 45,4 & 443 & $54,6^{*}$ & 812 & 36,1 \\
\hline & 40 to 49 & 273 & 48,1 & 294 & 51,9 & 566 & 25,1 \\
\hline & 50 to 59 & 262 & $59,9^{*}$ & 175 & 40,1 & 437 & 19,4 \\
\hline & 60 and more & 232 & $58,3^{*}$ & 167 & 41,7 & 399 & 17,7 \\
\hline \multirow{5}{*}{$\begin{array}{l}\text { Academic } \\
\text { experience }\end{array}$} & under 10 & 300 & 47,9 & 326 & $52,1^{*}$ & 627 & 27,7 \\
\hline & 10 to 19 & 280 & 43,8 & 359 & $56,2^{*}$ & 640 & 28,3 \\
\hline & 20 to 29 & 221 & $57,2^{*}$ & 165 & 42,8 & 386 & 17,1 \\
\hline & 30 to 39 & 255 & $57,6^{*}$ & 188 & 42,4 & 443 & 19,6 \\
\hline & 40 and more & 107 & $64,6^{*}$ & 59 & 35,4 & 166 & 7,3 \\
\hline \multirow{7}{*}{$\begin{array}{l}\text { Academic } \\
\text { field }\end{array}$} & HUM & 251 & 48,1 & 271 & 51,9 & 522 & 22,9 \\
\hline & $\mathrm{SOC}$ & 86 & 36,3 & 151 & $63,7^{*}$ & 238 & 10,4 \\
\hline & PHYSMATH & 144 & $78,6^{*}$ & 39 & 21,4 & 183 & 8 \\
\hline & LIFE & 256 & $63,3^{*}$ & 148 & 36,7 & 404 & 17,7 \\
\hline & ENGITECH & 256 & 49,3 & 264 & 50,7 & 519 & 22,8 \\
\hline & AGRICULT & 62 & 39,5 & 95 & $60,5^{*}$ & 157 & 6,9 \\
\hline & MEDHEALTH & 117 & 45,7 & 139 & $54,3^{*}$ & 256 & 11,2 \\
\hline
\end{tabular}




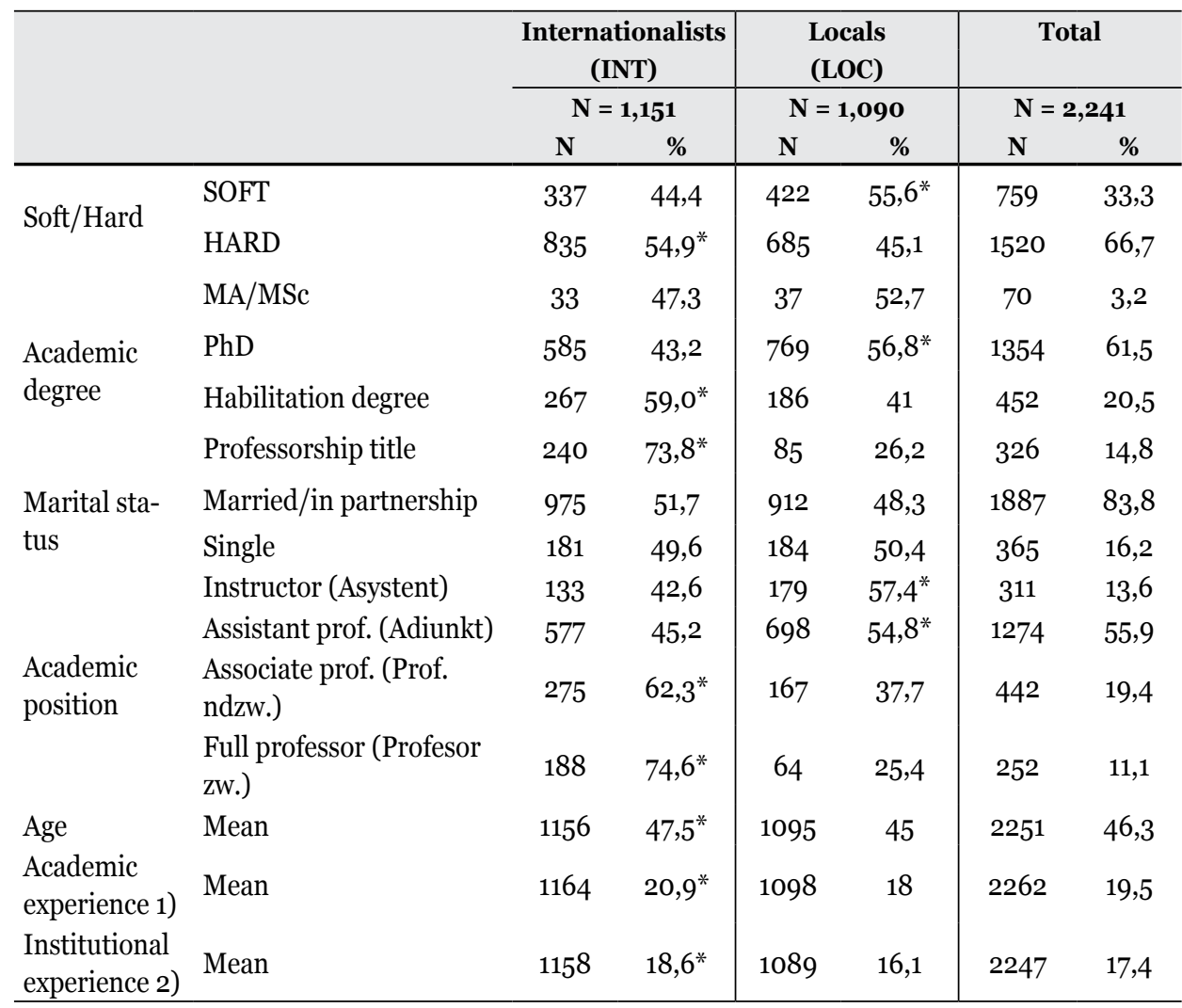

(1) Doświadczenie akademickie odnosi się do liczby lat, jakie upłynęły od momentu podjęcia pierwszej pracy w pełnym wymiarze czasu pracy (z wyjątkiem stanowiska asystenta naukowego i dydaktycznego w sektorze szkolnictwa wyższego; pytanie A6). (2) Doświadczenie instytucjonalne odnosi się do liczby lat spędzonych w obecnej instytucji. * $\mathrm{p}<0,05$

H2. Hipoteza dotycząca wieku i stanowiska - internacjonaliści są zazwyczaj starsi i zajmuja wyższe stanowiska.

Umiędzynarodowienie w badaniach jest działaniem charakterystycznym dla starszych naukowców, którego poziom rośnie wraz z wiekiem, doświadczeniem akademickim, stopniem naukowym i stanowiskiem akademickim (tabela 2). Po pierwsze poziom umiędzynarodowienia wyraźnie rośnie wraz z wiekiem; internacjonaliści stanowią mniejszość w grupie wiekowej 30-39 lat, ale większość we wszystkich starszych grupach wiekowych. Po drugie poziom umiędzynarodowienia wyraźnie rośnie wraz z doświadczeniem akademickim; mniejszość naukowców z doświadczeniem krótszym niż 20 lat to internacjonaliści, ale większość z co najmniej 20 letnim doświadczeniem to internacjonaliści, z najwyższym odsetkiem w najstarszej kategorii wiekowej. 
I wreszcie, poziom umiędzynarodowienia rośnie wraz ze stopniem naukowym i zajmowanym stanowiskiem akademickim; mniejszość doktorantów i adiunktów to internacjonaliści w porównaniu $\mathrm{z}$ dwiema trzecimi naukowców posiadających tytuł profesora i zatrudnionymi jako profesorowie zwyczajni. W próbie średni wiek internacjonalistów wyniósł 47,5 roku, a ich średnie doświadczenie akademickie i doświadczenie instytucjonalne (tj. zatrudnienie w tej samej instytucji) wynosiły odpowiednio 20,9 roku i 18,6 roku.

Polscy internacjonaliści wpisują się zatem w znane wzorce (Rostan i Ceravolo 2015; Rostan, Ceravolo i Metcalfe 2015; Shin, Jung i Kim 2014) - poziom umiędzynarodowienia jest niższy wśród młodszych pokoleń i wyższy wśród pokoleń starszych. We wszystkich przedziałach wiekowych najwyższy poziom występuje w naukach fizycznych i matematycznych, a najniższy w naukach społecznych (Kyvik i Larsen 1997; Smeby i Gornitzka 2008) (zob. rys. 1). Rozkład polskich naukowców według klastrów dyscyplin odpowiada w przybliżeniu ich rozkładowi w systemie szkolnictwa wyższego. Udział internacjonalistów rośnie wraz ze wzrostem stanowiska akademickiego we wszystkich dyscyplinach, zarówno twardych, jak i miękkich. W przypadku doktorów w dziedzinach SOC, AGRICULT i MEDHEALTH liczba ta wynosi około jednej trzeciej w porównaniu z dwiema trzecimi w PHYSMATH. W przypadku posiadaczy habilitacji, udział ten jest najniższy w AGRICULT i SOC, a najwyższy w PHYSMATH i LIFE. Wreszcie, w przypadku profesorów tytularnych, ośmiu-dziewięciu na dziesięciu profesorów w PHYSMATH, LIFE i MEDHEALT to internacjonaliści w porównaniu z około połową w SOC i AGRICULT (zob. rys. 2). Hipotezę 2 wspierają dane.

Rysunek 1. Internacjonaliści według grupy wiekowej i klastra dyscyplin (\%)
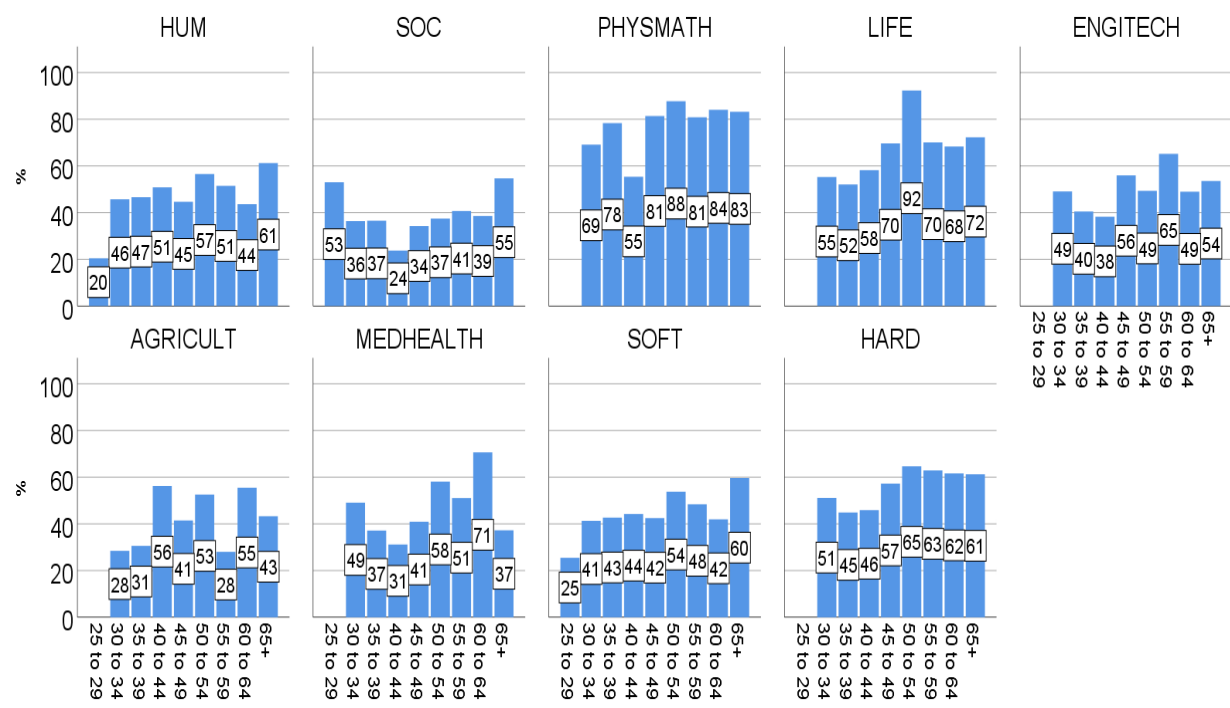
Rysunek 2. Internacjonaliści według stopnia naukowego i klastra dyscyplin (\%)

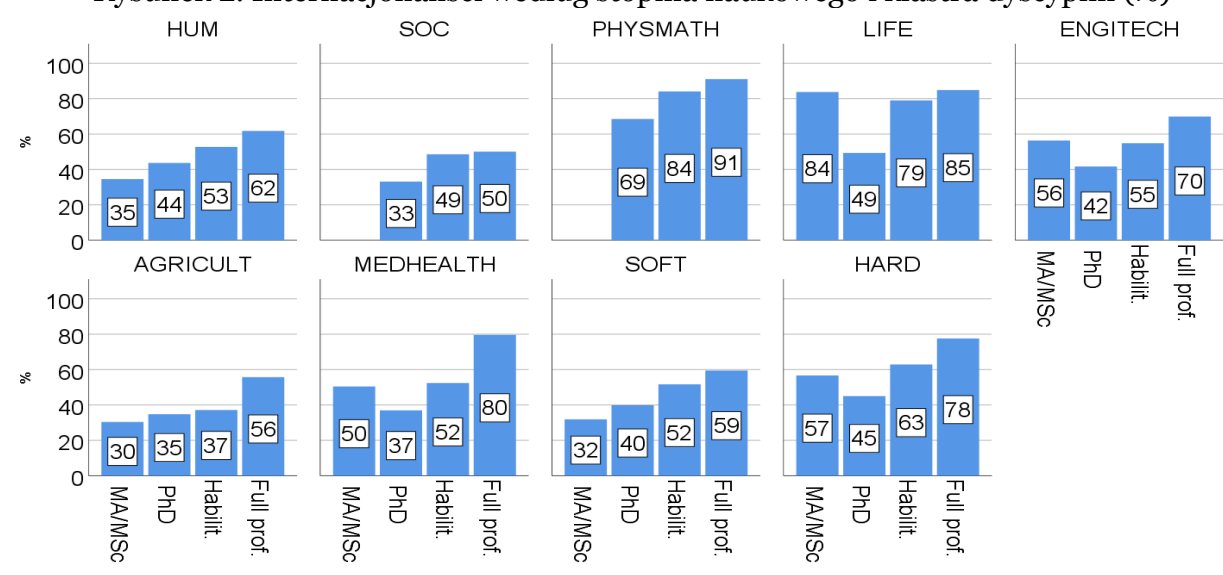

H3. Hipoteza dotyczaca rozkładu według dziedzin nauki - internacjonaliści wywodzą się raczej z dziedzin twardych nïz miękkich.

Klaster miękkich dziedzin akademickich obejmuje HUM i SOC, natomiast klaster twardych dziedzin akademickich obejmuje PHYSMATH, LIFE, ENGITECH, AGRICULT i MEDHEALTH. Wszystkie inne dziedziny (OTHERS) zostały usunięte $\mathrm{z}$ analizy. Poziom umiędzynarodowienia jest silnie uzależniony od dziedziny; internacjonaliści stanowią tylko jedną trzecią naukowców w dziedzinie nauk społecznych, ale ponad trzy czwarte w dziedzinie nauk fizycznych i matematycznych. Ponieważ stanowią oni mniejszość w dziedzinach miękkich i większość w dziedzinach twardych (tabela 3), hipoteza 3 jest zasadna.

Tabela 3. Naukowcy deklarujący współpracę z kolegami z zagranicy (D1/4) według klastra dyscyplin (\%)

\begin{tabular}{lccc}
\hline & Yes - Internationalists & No - Locals & Total \\
HUM & 48,1 & 51,9 & 100 \\
SOC & 36,3 & $63,7^{* * *}$ & 100 \\
PHYSMATH & $78,6^{* * *}$ & 21,4 & 100 \\
LIFE & $63,3^{* * *}$ & 36,7 & 100 \\
ENGITECH & 49,3 & 50,7 & 100 \\
AGRICULT & 39,5 & $60,5^{*}$ & 100 \\
MEDHEALTH & 45,7 & $54,3^{*}$ & 100 \\
Total & $51,4^{* *}$ & 48,6 & 100 \\
\hline Soft combined & 44,4 & $55,6^{* * *}$ & 100 \\
\hline Hard combined & $54,9^{* * *}$ & 45,1 & 100 \\
\hline & ${ }^{*} \mathrm{p}<0,05 ;{ }^{* *} \mathrm{p}<0,01 ;{ }^{* * *} \mathrm{p}<0,001$ &
\end{tabular}


H4. Hipoteza dotycząca wspótpracy krajowej - internacjonaliści wspótpracuja $w$ kraju częściej niż miejscowi.

Polscy internacjonaliści współpracują także częściej w kraju - innymi słowy, współpraca międzynarodowa nie wyklucza współpracy krajowej (D1/3: „Czy w prowadzonych badaniach współpracuje Pan(i) z naukowcami z innych instytucji w Polsce?”). Tylko co piąty internacjonalista (20,5\%) nie współpracuje w kraju (tabela 4). Możemy jedynie spekulować na temat przyczyn braku współpracy krajowej, do których można zaliczyć brak czasu na oba rodzaje współpracy, brak środków finansowych na współpracę krajową, niższą atrakcyjność partnerów krajowych czy też ograniczone możliwości wspólnego wydawania publikacji międzynarodowych z nimi. Co ciekawsze, tylko połowa miejscowych współpracuje w kraju - innymi słowy, połowa z tych, którzy nie współpracują międzynarodowo, również nie współpracuje w kraju. Efekt ten jest zróżnicowany w różnych dziedzinach; około dwóch trzecich miejscowych w naukach humanistycznych i społecznych nie współpracuje ze sobą również w kraju innymi słowy, w miękkich dyscyplinach akademickich dominuje model „samotnego uczonego" (63,3\% miejscowych w tych dyscyplinach nie prowadzi również współpracy krajowej w badaniach). Największy odsetek naukowców współpracujących ze sobą na poziomie krajowym dotyczy nauk przyrodniczych $(71,6 \%)$.

Tabela 4. Naukowcy deklarujący współpracę krajową (D1/3) według klastra dyscyplin (\%)

\begin{tabular}{lcccc}
\hline & \multicolumn{2}{c}{ Internationalists (INT) } & \multicolumn{2}{c}{ Locals (LOC) } \\
\cline { 2 - 5 } & $\begin{array}{c}\text { Collaborate } \\
\text { domestically }\end{array}$ & $\begin{array}{c}\text { Do not collaborate } \\
\text { domestically }\end{array}$ & $\begin{array}{c}\text { Collaborate } \\
\text { domestically }\end{array}$ & $\begin{array}{c}\text { Do not collaborate } \\
\text { domestically }\end{array}$ \\
\hline HUM & $72,1^{* * *}$ & 27,9 & 36,9 & $63,1^{* * *}$ \\
SOC & 75,5 & 24,5 & 36,5 & $63,5^{* * *}$ \\
PHYSMATH & 74,0 & 26,0 & 46,7 & 53,3 \\
LIFE & $86,7^{* * *}$ & 13,3 & $71,6^{* * *}$ & 28,4 \\
ENGITECH & 78,2 & 21,8 & $56,8^{*}$ & 43,2 \\
AGRICULT & $91,7^{* *}$ & 8,3 & $59,8^{*}$ & 40,2 \\
MEDHEALTH & 85,6 & 14,4 & 48,6 & 51,4 \\
Total & 79,5 & 20,5 & 50,0 & 50,0 \\
\hline Soft combined & $73,0^{* * *}$ & 27,0 & 36,7 & $63,3^{* * *}$ \\
Hard combined & $82,1^{* * *}$ & 17,9 & $58,2^{* * *}$ & 41,8 \\
\hline \multicolumn{5}{c}{$\mathrm{p}<0,05 ;{ }^{* *} \mathrm{p}<0,01 ;{ }^{* * *} \mathrm{p}<0,001$} \\
\end{tabular}

We wszystkich klastrach (tabela 5) odsetek internacjonalistów współpracujących w kraju jest wyższy niż odsetek miejscowych współpracujących w kraju. Ponieważ różnice są istotne statystycznie dla wszystkich klastrów, z wyjątkiem nauk społecznych i rolniczych, hipoteza 4 jest częściowo zasadna. 
Tabela 5. Krajowa współpraca naukowa - naukowcy współpracujący na poziomie krajowym w badaniach według klastra dyscyplin INT vs. LOC (\%)

\begin{tabular}{lcccccc}
\hline & $\begin{array}{c}\text { All collabo- } \\
\text { rating do- } \\
\text { mestically } \\
\text { (ALL) }\end{array}$ & $\begin{array}{c}\text { International- } \\
\text { ists collaborat- } \\
\text { ing domestically } \\
\text { (INT) }\end{array}$ & $\begin{array}{c}\text { Locals col- } \\
\text { laborating } \\
\text { domestically } \\
\text { (LOC) }\end{array}$ & $\mathbf{Z}$ & p-value & $\begin{array}{c}\text { Significant- } \\
\text { ly higher } \\
\text { percentage }\end{array}$ \\
\hline HUM & 54,4 & 63,9 & 36,1 & 6,530 & 0,006 & INT \\
SOC & 51,3 & 53,5 & 46,5 & 1,066 & 0,227 & - \\
PHYSMATH & 68,1 & 85,2 & 14,8 & 11,076 & $<0,001$ & INT \\
LIFE & 81,3 & 67,4 & 32,6 & 8,877 & 0,002 & INT \\
ENGITECH & 67,9 & 56,8 & 43,2 & 3,560 & 0,036 & INT \\
AGRICULT & 73,2 & 50,0 & 50,0 & 0,006 & 0,994 & - \\
MEDHEALTH & 66,8 & 59,7 & 40,3 & 3,550 & 0,036 & INT \\
\hline Soft & 53,4 & 60,8 & 39,2 & 6,047 & 0,008 & INT \\
Hard & 71,8 & 63,0 & 37,0 & 12,055 & $<0,001$ & INT \\
\hline Total & 65,8 & 62,4 & 37,6 & 13,444 & $<0,001$ & INT \\
\hline
\end{tabular}

\subsection{Indywidualna produktywność naukowa a współpraca międzynarodowa}

H5. Hipoteza dotycząca poziomu produktywności badawczej - internacjonaliści sq bardziej produktywni niż miejscowi.

Hipoteza ta została przetestowana przy użyciu standardowej miary liczby recenzowanych artykułów (PRA) oraz miar IC-PRA i ENG-PRA w celu uzyskania bardziej szczegółowego opisu. Średnia produktywność badawcza została podsumowana w tabelach 6-8 zestawiających miejscowych (lewy panel) i internacjonalistów (prawy panel) według typu produktywności (miary PRA, IC-PRA i ENG-PRA) oraz klastra dyscyplin. W niniejszym tekście przyjęto definicję produktywności badawczej, zastosowaną przez Teodorescu (2000: 206), jako „samodzielnie deklarowaną liczbę artykułów i rozdziałów w książkach naukowych, które respondent opublikował w ciągu trzech lat poprzedzających badanie ankietowe”. Na przykład w wierszu 1 średnia wartość PRA dla trzyletniego okresu referencyjnego wynosi 3,2 dla wszystkich miejscowych i 4,3 dla wszystkich internacjonalistów w klastrze dyscyplin humanistycznych (HUM); jako że tylko 58,3\% miejscowych i 56,9\% internacjonalistów rzeczywiście publikowało w tym okresie, średnia wynosi odpowiednio 5,4 i 6,5, przy medianach odpowiednio 3,6 i 6,1. 95\% przedział ufności dla średniej (4,6 artykułu jako dolna granica i 6,2 artykułu jako górna granica) wskazuje, że przedział 4,6-6,2 obejmuje wskazaną liczbę artykułów $\mathrm{z}$ dziewięćdziesięciopięcioprocentową pewnością; podobnie internacjonaliści w naukach humanistycznych publikują średnio 6,5 artykułu, z 95\% przedziałem ufności $5,3-8,5$. W kontekście europejskim statystyczny polski naukowiec publikuje niewiele 
prac naukowych, a w statystycznym indywidualnym dorobku naukowym dominują publikacje krajowe (Kwiek 2015b; Kwiek 2016b) - co potwierdzają analizy danych z Polskiej Bibliografii Naukowej (PBN) na poziomie instytucjonalnym.

Jak pokazuje tabela 7, międzynarodowe współautorstwo publikacji jest marginalne dla polskich badaczy miejscowych $(2,1 \%)$ i wyższe (ale wciąż stosunkowo niskie) dla internacjonalistów (13,8\%). W przypadku PHYSMATH udział ten wynosi prawie 50\%, a w przypadku LIFE i AGRICULT około 40\%. Na drugim końcu spektrum, w ramach nauk humanistycznych i społecznych, internacjonaliści mieszczą się w przedziale 15-20\%. Średnia dla miękkich dziedzin akademickich wynosi 15,0\%, a dla dziedzin twardych $37,6 \%$.

Jak pokazano w tabeli 8, około jedna trzecia miejscowych publikuje w języku angielskim (36,3\%), w porównaniu z 51,7\% internacjonalistów (czyli osób współpracujących na arenie międzynarodowej). Znowu najwyższy odsetek odnotowuje PHYSMATH, gdzie sześć na dziesięć osób (miejscowych i internacjonalistów) publikuje w języku angielskim. Ogólnie rzecz biorąc, polscy internacjonaliści pod względem wzorców publikowania różnią się od miejscowych w sposób fundamentalny. Dodatkowo internacjonaliści są silnie zróżnicowani ze względu na dyscyplinę akademicką, a w szczególności ze względu na podział na dziedziny miękkie i twarde.

Co ciekawe, udział publikacji IC-PRA w puli publikacji PRA dla internacjonalistów jest na ogół znacznie wyższy we wszystkich klastrach innych niż ENGITECH (zob. rys. 3). Internacjonaliści wydają więcej publikacji i więcej publikacji z kolegami z zagranicy, ale istnieją znaczne różnice dyscyplinarne. Wśród internacjonalistów w klastrze PHYSMATH prawie 70\% publikacji jest współautorstwa międzynarodowego; w klastrach MEDHEALTH i LIFE odsetek ten wynosi około 50\%, podczas gdy w klastrach HUM i SOC nieco ponad 30\%.

We wszystkich klastrach internacjonaliści (czyli 51,4\% wszystkich naukowców) wydają ponad 90\% międzynarodowych publikacji współautorskich (tabela 9); a w klastrach PHYSMATH, SOC i LIFE udział ten wynosi aż 97-99,9\%. Oznacza to, że naukowcy pracujący w tych klastrach, którzy współpracują w skali międzynarodowej, wydają prawie wszystkie publikacje we współautorstwie międzynarodowym powstające w tych klastarch. Oznacza to z kolei, że brak współpracy międzynarodowej jest jednoznaczny z brakiem publikacji we współautorstwie międzynarodowym. Nie współpracujesz międzynarodowo - nie publikujesz w międzynarodowym współautorstwie.

Internacjonaliści są również odpowiedzialni za 75,0\% wszystkich polskich publikacji w języku angielskim (miara ENG-PRA). W klastrach PHYSMATH i LIFE są oni odpowiedzialni za ponad 80\% publikacji w języku angielskim. Miejscowi (jak podkreślamy, około połowy polskiego środowiska naukowego) wydają jedną czwartą wszystkich publikacji w języku angielskim. Innymi słowy brak współpracy międzynarodowej jest silnie skorelowany z publikowaniem wyłącznie w języku polskim. 

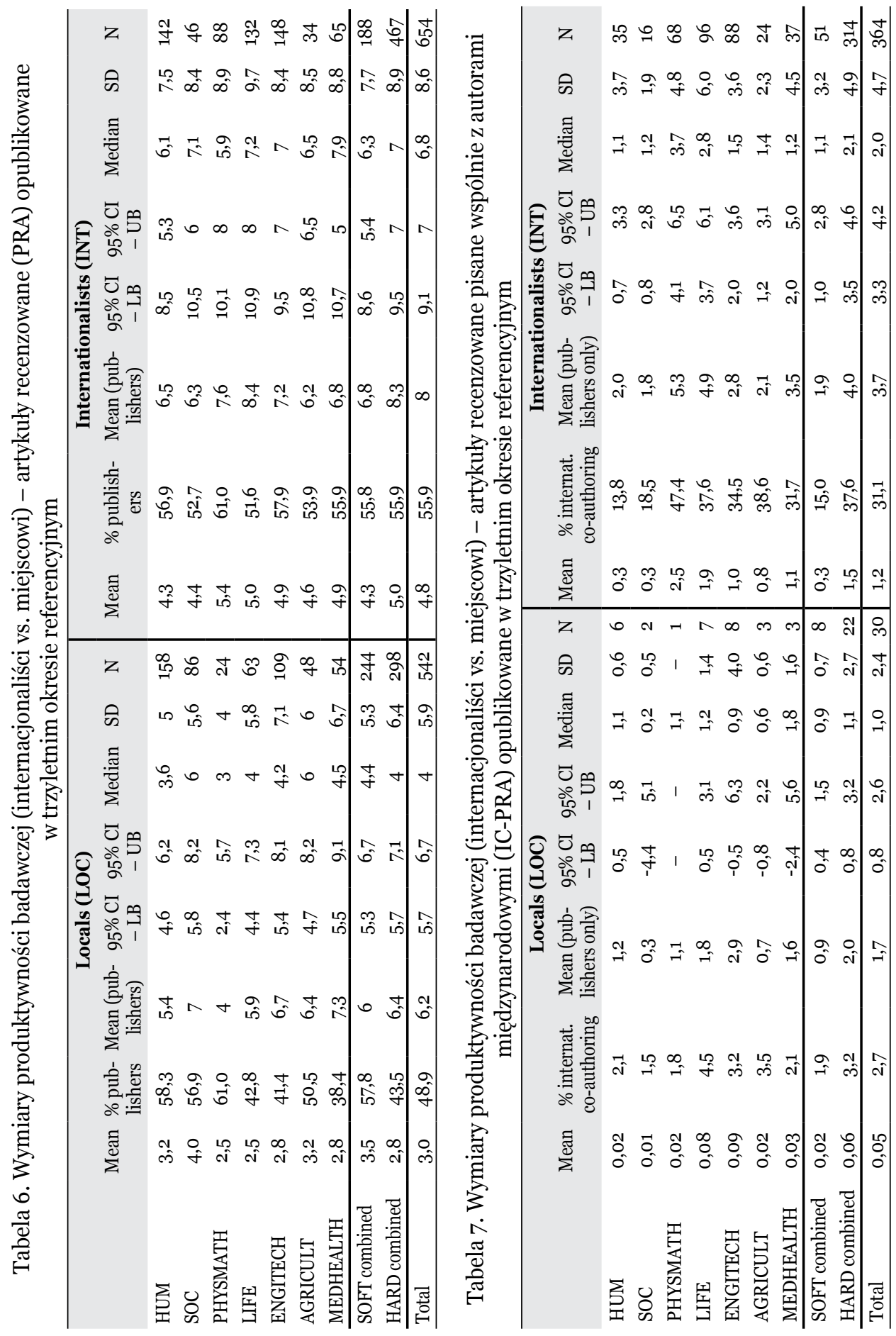


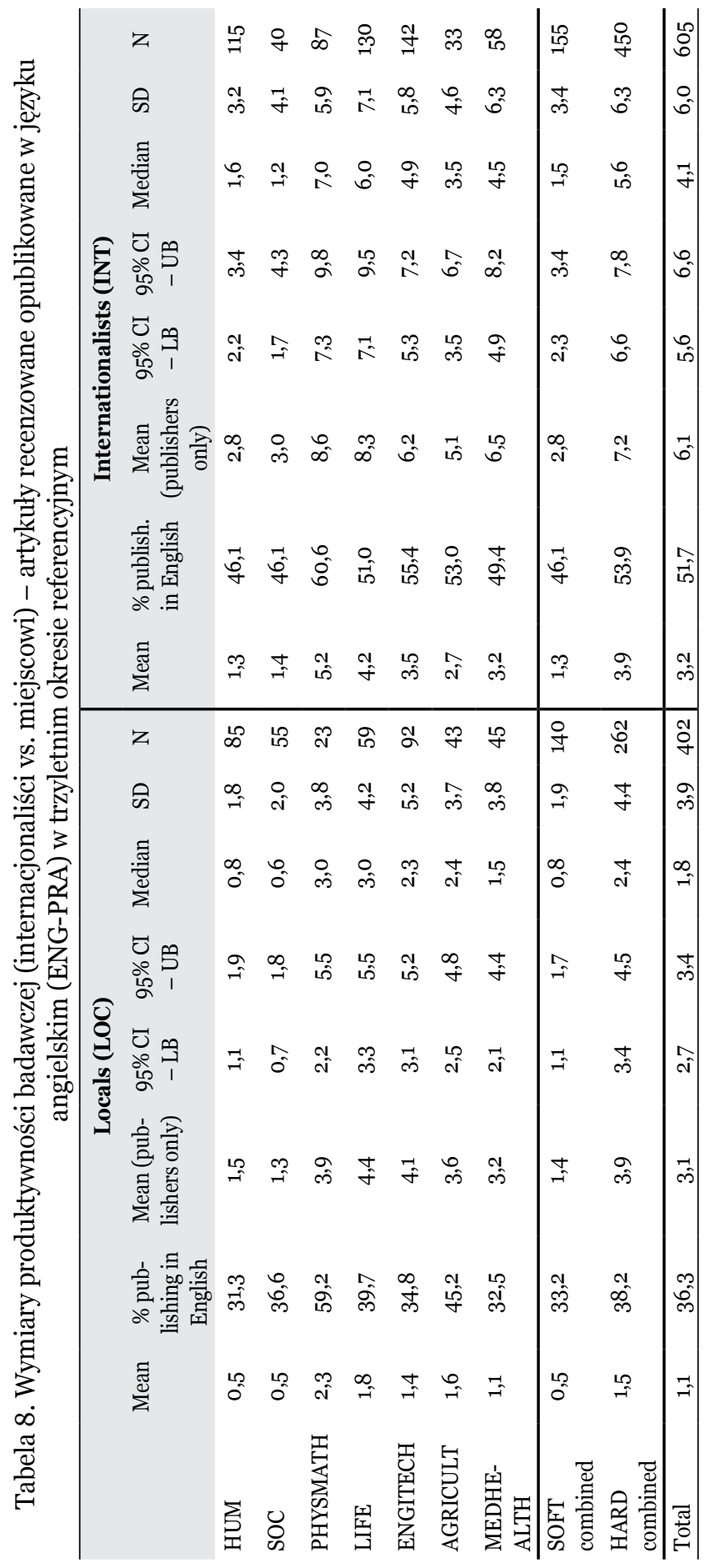


Rysunek 3. Produktywność badawcza według klastra dyscyplin - internacjonaliści (INT) vs. miejscowi (LOC)

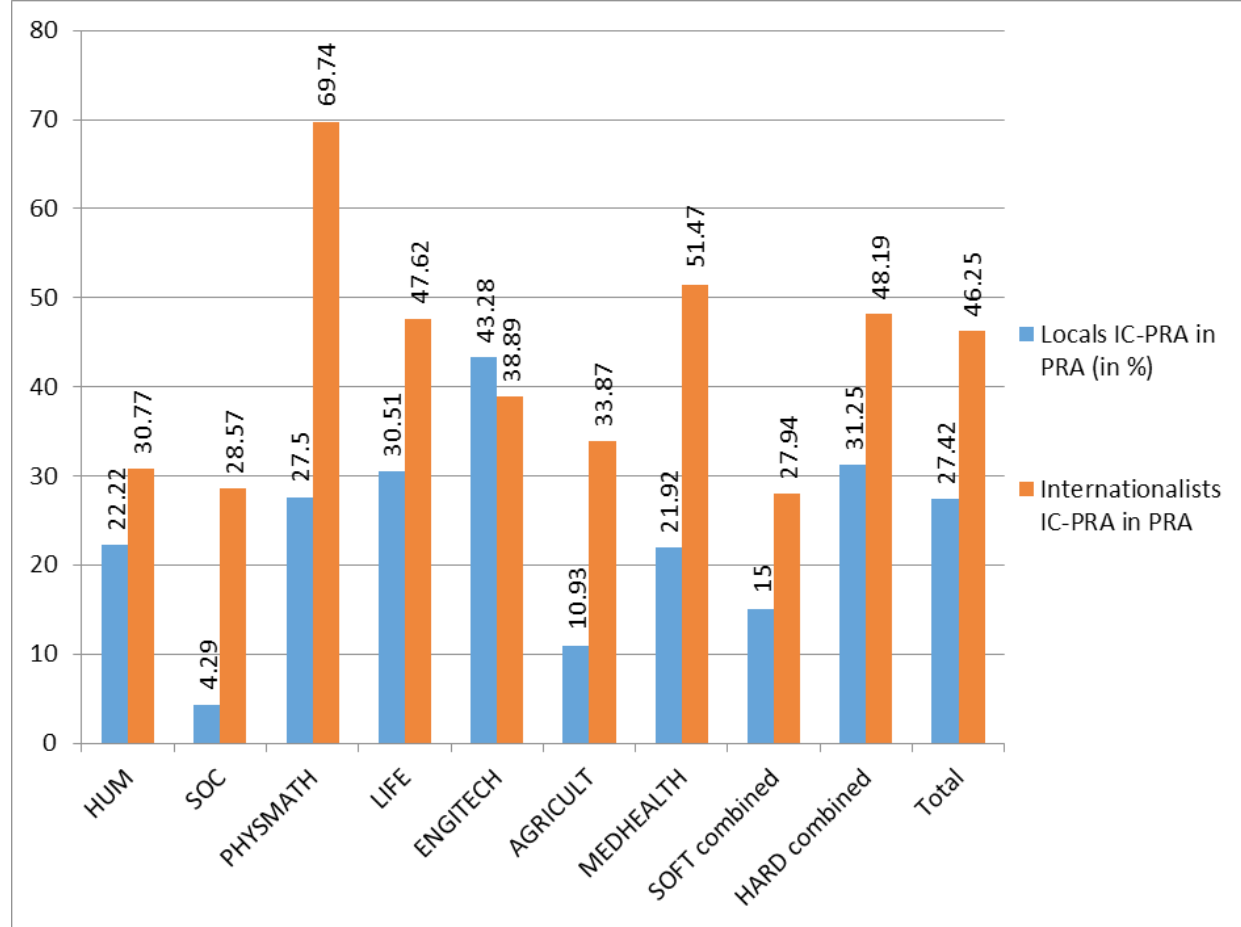

Objaśnienie: odsetek publikacji IC-PRA w publikacjach PRA - artykuły recenzowane o międzynarodowym współautorstwie i ekwiwalenty artykułów w recenzowanych artykułach opublikowane w trzyletnim okresie referencyjnym. Wyniki są statystycznie istotne dla wszystkich klastrów.

Tabela 9. Przeciętne wartości produkcji naukowej polskich internacjonalistów jako odsetek całkowitej produkcji naukowej

\begin{tabular}{lccc}
\hline \multicolumn{1}{c}{ Academic cluster } & INT (\%) & IC-PRA & ENG-PRA \\
HUM & 48,1 & 91,1 & 71,6 \\
SOC & 36,3 & 97,4 & 62,8 \\
PHYSMATH & 78,6 & 99,8 & 89,3 \\
LIFE & 63,3 & 97,6 & 80,6 \\
ENGITECH & 49,3 & 91,1 & 69,9 \\
AGRICULT & 39,5 & 95,6 & 51,9 \\
MEDHEALTH & 45,7 & 96,6 & 72,0 \\
Total (mean) & 51,4 & 96,4 & 75,0 \\
\hline SOFT combined & 44,4 & 92,8 & 69,0 \\
HARD combined & 54,9 & 96,6 & 75,9 \\
\hline
\end{tabular}

Objaśnienie: według klastra dyscyplin naukowych, według kategorii produktywności (IC-PRA i ENG-PRA) (w procentach). 
Produktywność badawcza polskich naukowców jest silnie skorelowana z typem współpracy naukowej; jest ona konsekwentnie niższa dla polskich naukowców, którzy nie uczestniczą we współpracy międzynarodowej we wszystkich klastrach i według wszystkich stosowanych miar. Rodzaj współautorstwa publikacji jest również silnie skorelowane z międzynarodową współpracą naukową i waha się od 1,2 razy więcej w przypadku miejscowych (dla MEDHEALTH) do 5 razy więcej w klastrach fizyki i matematyki oraz nauk społecznych. Natomiast naukowcy, którzy nie współpracują w skali międzynarodowej, deklarują zaledwie $3,2 \%$ swoich publikacji jako powstałych we współpracy międzynarodowej w dziedzinach nauk ścisłych i nie więcej niż 1,9\% w dziedzinach miękkich (tabela 9). Wniosek dla polityki naukowej jest prosty: brak współpracy międzynarodowej oznacza brak współautorstwa międzynarodowego (co jest zgodne z ustaleniami z Kwiek 2018b dla naukowców europejskich).

Wzorzec ten jest konsekwentnie taki sam dla wszystkich naukowców (internacjonalistów i miejscowych) ze wszystkich klastrów dyscyplin, zarówno w Polsce, jak i w systemach europejskich. Wśród tych, którzy nie współpracują na arenie międzynarodowej, tylko marginalny odsetek publikacji jest tworzony wspólnie z kolegami z innych krajów. Naukowcy ci mają jednak znaczący udział w profesji akademickiej w całej Europie: 47,5\% w przypadku dziedzin zawodowych, 40,0\% w inżynierii, $31,9 \%$ w naukach humanistycznych i społecznych, 39,6\% w naukach przyrodniczych i medycznych oraz 25,3\% w naukach fizycznych i matematycznych (na podstawie próby 17211 naukowców z 11 systemów Europy; Kwiek 2019: 143).

\subsection{Produktywność indywidualna według typu publikacji}

Produktywność indywidualna może być również badana według rodzaju publikacji, wykraczając poza artykuły recenzowane (zob. np. Sooryamoorthy 2014). Dla obecnych celów, pytania ankiety zostały sformułowane w następujący sposób: „Ile naukowych projektów spośród wymienionych poniżej rodzajów ukończył Pan(i) w ciągu ostatnich trzech lat? (pytanie $\mathrm{D} 4$ ), z oddzielnymi odpowiedziami na pytania: „autorstwo lub współautorstwo książki naukowej” (D4/1), „redakcja lub współredakcja książki naukowej” (D4/2), ,artykuł opublikowany w recenzowanym periodyku lub rozdział w książce naukowej” (D4/3), „raport badawczy/monografia napisana w ramach projektu badawczego" (D4/4), „wystąpienie prezentowane podczas konferencji naukowej” (D4/5) oraz „artykuł popularno-naukowy napisany dla gazety lub czasopisma" (D4/6).

Kolejne pytanie (D5) zostało sformułowane w następujący sposób: „Jaki procent Pan(a) publikacji w ostatnich trzech latach byl”: „poddany procesowi recenzyjnemu” (D5/6), „opublikowany w języku innym niż język wykładowy w Pana(i) uczelni” (D5/1), „współautorstwem z naukowcami pracującymi zagranicą?” (D5/3). 
W badaniu dokonano wyraźnego rozróżnienia pomiędzy różnymi typami publikacji; co ważne, polscy naukowcy są przyzwyczajeni do liczenia różnych typów publikacji dla celów sprawozdawczości instytucjonalnej.

Tabela 10. Średnia indywidualna produktywność badawcza według typu publikacji

\begin{tabular}{|c|c|c|c|c|c|c|c|c|c|c|c|c|c|}
\hline & \multicolumn{4}{|c|}{$\begin{array}{l}\text { Internationalists } \\
\text { (INT) }\end{array}$} & \multicolumn{4}{|c|}{$\begin{array}{l}\text { Locals } \\
\text { (LOC) }\end{array}$} & \multicolumn{4}{|c|}{ ALL } & \multirow{2}{*}{$\begin{array}{c}\text { LOC } \\
\text { vs. } \\
\text { INT } \\
\text { LOC = } \\
100 \%\end{array}$} \\
\hline & Mean & SD & Min & Max & Mean & SD & Min & Max & Mean & SD & Min & Max & \\
\hline $\begin{array}{l}\text { Books authored/co-au- } \\
\text { thored }\end{array}$ & $0,6^{* *}$ & 1,2 & 0 & 18 & 0,4 & 1,2 & 0 & 30 & 0,5 & 1,2 & 0 & 30 & 150,0 \\
\hline Books edited/co-edited & $0,4^{* * *}$ & 0,9 & 0 & 9 & 0,3 & 0,8 & 0 & 7 & 0,3 & 0,8 & 0 & 9 & 133,3 \\
\hline $\begin{array}{l}\text { Research reports/mon- } \\
\text { ographs written for } \\
\text { a funded project }\end{array}$ & $0,8^{* * *}$ & 1,8 & 0 & 25 & 0,4 & 1,3 & 0 & 30 & 0,6 & 1,6 & 0 & 30 & 200,0 \\
\hline Papers at a conference & $5,0^{* * *}$ & 6 & 0 & 30 & 3,0 & 5 & 0 & 30 & 4 & 6 & 0 & 30 & 166,7 \\
\hline $\begin{array}{l}\text { Articles (newsp. or } \\
\text { magazine) }\end{array}$ & 1,1 & 3 & 0 & 30 & 1,0 & 3,1 & 0 & 30 & 1,1 & 3 & 0 & 30 & 100,0 \\
\hline $\begin{array}{l}\text { Peer reviewed articles } \\
\text { (PRA) }\end{array}$ & $4,79^{* * *}$ & 6,63 & 0 & 33 & 3,04 & 5,17 & 0 & 30 & 3,94 & 6,03 & 0 & 33 & 157,6 \\
\hline $\begin{array}{l}\text { Peer reviewed article } \\
\text { equivalents (PRAE) }\end{array}$ & $8,3^{* * * *}$ & 11 & 0 & 106,2 & 5,6 & 9,1 & 0 & 165 & 7 & 10,2 & 0 & 165 & 148,2 \\
\hline $\begin{array}{l}\text { Int. co-authored } \\
\text { peer-rev. articles } \\
\text { (IC-PRA) }\end{array}$ & $1,16^{* * *}$ & 3,15 & 0 & 33 & 0,05 & 0,47 & 0 & 13,3 & 0,62 & 2,35 & 0 & 33 & 2320,0 \\
\hline $\begin{array}{l}\text { Int. co-authored } \\
\text { peer-rev. article equiv- } \\
\text { alents (IC-PRAE) }\end{array}$ & $1,6^{* * *}$ & 4,3 & 0 & 42,8 & 0,1 & 0,7 & 0 & 20 & 0,9 & 3,2 & 0 & 42,8 & 1600,0 \\
\hline $\begin{array}{l}\text { English language } \\
\text { peer-reviewed articles } \\
\text { (ENG-PRA) }\end{array}$ & $3,2^{* * *}$ & 5,3 & 0 & 33 & 1,1 & 2,8 & 0 & 30 & 2,2 & 4,4 & 0 & 33 & 290,9 \\
\hline $\begin{array}{l}\text { English language } \\
\text { peer-rev. article equiv- } \\
\text { alents (ENG-PRAE) }\end{array}$ & $4,7^{* * *}$ & 7,6 & 0 & 58,4 & 1,7 & 3,9 & 0 & 43,2 & 3,3 & 6,3 & 0 & 58,4 & 276,5 \\
\hline
\end{tabular}

${ }^{*} \mathrm{p}<0,05 ;{ }^{* *} \mathrm{p}<0,01 ;{ }^{* * *} \mathrm{p}<0,001$

Objaśnienie: internacjonaliści INT, miejscowi LOC oraz wszyscy naukowcy ALL dla trzyletniego okresu referencyjnego, a także różnica między internacjonalistami a miejscowymi (LOC $=100 \%)$ według typu publikacji.

Instrument badawczy ułatwil porównywanie produktywności internacjonalistów i miejscowych w zakresie książek naukowych autorskich i współautorskich oraz redagowanych i współredagowanych, artykułów publikowanych w książkach lub czasopismach (i ekwiwalentów artykułów), raportów badawczych lub monografii napisanych na potrzeby sfinansowanego projektu, fachowych artykułów pisanych 
dla szerszego grona odbiorców, artykułów współautorskich międzynarodowych (i ekwiwalentów tych artykułów), artykułów w języku angielskim (i ekwiwalentów tych artykułów) oraz referatów prezentowanych na konferencjach naukowych. Wartości średnich, odchyleń standardowych oraz wartości minimalne i maksymalne produktywności pokazuje tabela 10. Ogólnie rzecz biorąc, internacjonaliści okazali się bardziej produktywni niż miejscowi w odniesieniu do wszystkich badanych elementów produktywności; wszystkie różnice były statystycznie istotne $(\mathrm{p}<0,001)$ z wyjątkiem specjalistycznych artykułów pisanych dla gazet i czasopism.

Przeciętnie internacjonaliści są znacznie bardziej produktywni pod względem publikacji napisanych we współautorstwie międzynarodowym. Zakładając, że produktywność miejscowych wynosi 100\% (zob. LOC vs. INT w tabeli 10), produktywność internacjonalistów dla miary IC-PRA wynosi 2,320\% i 1,600\% dla miary IC-PRAE. Internacjonaliści stanowią również inny świat w porównaniu z miejscowymi pod względem międzynarodowego współautorstwa. Są prawie trzy razy bardziej produktywni pod kątem publikacji w języku angielskim. W przypadku miary ENG-PRA produktywność internacjonalistów wynosi 290,9\%, a w przypadku miary ENG-PRAE 276,5\% produktywności miejscowych. W przypadku innych typów publikacji produktywność internacjonalistów jest średnio o 30-70\% wyższa od produktywności miejscowych: dla książek autorskich i współautorskich wskaźnik ten wynosi 150\%, książek zredagowanych 133,3\%, dla artykułów 157,6\%, a dla ich ekwiwalentów (PRAE) 148,2\%, dla referatów konferencyjnych 166,7\% i dla raportów z badań 200\%. Krótko mówiąc, hipoteza 5 została zweryfikowana pozytywnie.

\subsection{Wyniki badań - analiza dwuwymiarowa \\ 4.3.1. Rozkład czasu pracy - internacjonaliści vs. miejscowi}

H6. Hipoteza dotyczq̨ca rozkładu czasu pracy - internacjonaliści pracują dhużej i poświęcają więcej czasu na badania, mniej na ksztatcenie i więcej na pracę administracyjna.

W tej części przedstawiamy wyniki dotyczące różnic w średniej liczbie godzin pracy, zwłaszcza średniej liczbie godzin pracy poświęcanej na badania, między dwiema subpopulacjami (INT i LOC). Nasze wyniki są oparte na dwustronnym teście $t$ dla dwóch średnich o hipotezie zerowej zakładającej równość średniego poziomu zjawiska w dwóch subpopulacjach, na poziomie istotności $\alpha=0,05$. Dla każdej pary o różnicy średnich istotnie różniących się od zera pojawia się w danej kolumnie symbol większej kategorii („INT” dla internacjonalistów i „LOC” dla miejscowych). Test $t$ dla dwóch średnich arytmetycznych (INT vs. LOC) został wykonany dla każdego z pięciu typów zbadanej działalności akademickiej i dla każdego klastra dyscyplin 
oraz dla połączonych klastrów dziedzin miękkich i dziedzin twardych (wszystkie różnice były istotne statystycznie, tabela 11).

Zbiór danych zawierał pięć wymiarów pracy akademickiej: kształcenie, badania, działalność na rzecz uczelni i usługowa typu non-profit, administracja i inne działania akademickie. Nacisk położono tutaj na różnice w średnich godzinach pracy internacjonalistów i miejscowych w każdym klastrze dyscyplin, w oparciu o tygodniowe godziny pracy w okresie, kiedy są prowadzone zajęcia i wtedy, kiedy ich nie ma w ramach roku akademickiego. Godziny te zostały uśrednione w skali roku, zakładając, że 60\% dla pierwszego okresu i 40\% dla okresu drugiego stanowi dobre przybliżenie w polskim systemie szkolnictwa wyższego.

Tabela 11. Zróżnicowanie czasu pracy według rodzaju działalności akademickiej i klastra dyscyplin w oparciu o wyniki testu $t$ dla równości średnich, internacjonaliści INT i miejscowi LOC

\begin{tabular}{|c|c|c|c|c|c|c|c|c|c|}
\hline & HUM & SOC & $\begin{array}{l}\text { PHYS } \\
\text { MATH }\end{array}$ & LIFE & $\begin{array}{l}\text { ENGI } \\
\text { TECH }\end{array}$ & $\begin{array}{l}\text { AGRI } \\
\text { CULT }\end{array}$ & $\begin{array}{c}\text { MED } \\
\text { HEALTH }\end{array}$ & $\begin{array}{c}\text { Soft } \\
\text { com- } \\
\text { bined }\end{array}$ & $\begin{array}{l}\text { Hard } \\
\text { com- } \\
\text { bined }\end{array}$ \\
\hline Teaching & & & & LOC & & & & & LOC \\
\hline Research & INT & INT & INT & INT & & & INT & INT & INT \\
\hline Service & & & & & & & & INT & \\
\hline $\begin{array}{l}\text { Administration } \\
\text { Other }\end{array}$ & & & & INT & & & INT & & INT \\
\hline Total & INT & INT & & & & & & INT & INT \\
\hline
\end{tabular}

Objaśnienie: pytanie B1: „Biorąc pod uwagę całą swoją aktywność zawodową, proszę wskazać, ile godzin w ciągu tygodnia przeznacza Pan(i) na każde z wymienionych poniżej zajęć w bieżącym roku akademickim" (średnia roczna: 60\% w okresie prowadzenia zajęć i 40\%, kiedy zajęcia nie są prowadzone)? W tabeli została przedstawiona grupa o statystycznie istotnie wyższej średniej.

Różnica w średnim tygodniowym czasie pracy internacjonalistów i miejscowych wynosi 4,4 godziny (zob. tabela 12). Pojawiający się tu obraz przedstawia polską akademię jako stosunkowo tradycyjną. Przeciętnie internacjonaliści poświęcają mniej czasu niż miejscowi na działalność dydaktyczną, znacznie więcej czasu (około 30\%) na badania, a także więcej czasu na obowiązki administracyjne. Istnieją jednak znaczne różnice między dyscyplinami w całkowitym średnim tygodniowym czasie pracy, od 5,9 godzin w przypadku nauk humanistycznych do 11,4 godzin w przypadku nauk społecznych (zob. tabela 17 w załącznikach).

Innymi słowy, najbardziej jaskrawego przykładu różnic dostarcza klaster nauk społecznych (SOC) - w porównaniu z polskimi miejscowymi w naukach społecznych, polscy internacjonaliści w tym obszarze poświęcają średnio 64 dodatkowe pełne dni robocze na pracę akademicką ( $\mathrm{tj}$. 11,4 godziny więcej w tygodniu x 46 tygodni rocznie, podzielone przez 8 godzin dziennie). Dokładniej rzecz ujmując, poświęcają oni 
średnio 9,4 dodatkowych godzin tygodniowo (lub 54 dodatkowe dni rocznie) na badania. Nic dziwnego, że internacjonaliści w dziedzinie nauk społecznych deklarują najdłuższy tygodniowy czas pracy i drugi najdłuższy czas poświęcany na badania (po naukach fizycznych i matematyce). Dla polskich internacjonalistów dłuższy czas pracy wydaje się standardem (zwłaszcza większa liczba godzin poświęconych na pracę badawczą). Różnice między dwoma typami naukowców są silniejsze w przypadku dziedzin miękkich (średnio 7,5 godziny tygodniowo) niż dziedzin twardych (2,7 godziny), znacznie silniej umiędzynarodowionych. Podsumowując, hipoteza 6 została potwierdzona.

Tabela 12. Zróżnicowanie godzin pracy ze względu na rodzaj działalności akademickiej (dla naukowców ze wszystkich klastrów dyscyplin łącznie) w oparciu o wyniki testu $t$ dla równości średnich, internacjonaliści INT i miejscowi LOC

\begin{tabular}{|c|c|c|c|c|c|c|c|}
\hline & \multicolumn{2}{|c|}{$\begin{array}{c}\text { Mean hours per } \\
\text { week (annualized) }\end{array}$} & \multirow{2}{*}{$\begin{array}{l}\text { T-sta- } \\
\text { tistics } \\
\text { value }\end{array}$} & \multirow{2}{*}{ P-value } & \multirow{2}{*}{$\begin{array}{l}\text { Significant- } \\
\text { ly larger } \\
\text { mean (INT } \\
\text { or LOC) }\end{array}$} & \multirow{2}{*}{$\begin{array}{c}\text { \% differ- } \\
\text { ence } \\
\text { (INT vs. } \\
\text { LOC) }\end{array}$} & \multirow{2}{*}{$\begin{array}{c}\text { Hours } \\
\text { per week } \\
\text { differ- } \\
\text { ence (INT } \\
\text { vs. LOC) }\end{array}$} \\
\hline & INT & LOC & & & & & \\
\hline Teaching & 14,8 & 16,0 & $-2,875$ & 0,004 & LOC & $-7,6$ & $-1,2$ \\
\hline Research & 22,3 & 17,0 & 9,201 & $<0,001$ & INT & 30,8 & 5,3 \\
\hline Service & 5,5 & 5,4 & 0,121 & 0,904 & - & 0,8 & 0,0 \\
\hline Administration & 6,7 & 5,6 & 3,749 & $<0,001$ & INT & 18,9 & 1,1 \\
\hline Other & 5,3 & 5,3 & 0,056 & 0,955 & - & 0,3 & 0,0 \\
\hline Total & 49,1 & 44,7 & 4,690 & $<0,001$ & INT & 9,8 & 4,4 \\
\hline
\end{tabular}

Objaśnienie: pytanie B1: „Biorąc pod uwagę całą swoją aktywność zawodową, proszę wskazać, ile godzin w ciągu tygodnia przeznacza Pan(i) na każde z wymienionych poniżej zajęć w bieżącym roku akademickim" (średnia roczna: 60\% w okresie prowadzenia zajęć i 40\%, kiedy zajęcia nie są prowadzone)?

\subsubsection{Ukierunkowanie na rolę kształceniową i badawczą: internacjonaliści vs. miejscowi}

H7. Hipoteza dotycząca orientacji na role akademickie - internacjonaliści są bardziej ukierunkowani na badania, a miejscowi na kształcenie.

Istniejąca literatura sugeruje, że umiędzynarodowienie badań jest skorelowane z silną orientacją badawczą (Rostan, Ceravolo i Metcalfe 2014; Shin i Cummings 2010; Teodorescu 2000). Polski system jako całość wyłania się z naszych badań jako całkowicie tradycyjny. Wyniki testu $z$ na równość dwóch frakcji oparte są na dwustronnym obszarze odrzucenia na poziomie istotności $\alpha=0,05$. Wykorzystując poprawkę Bonferroniego, testy zostały dostosowane do wszystkich porównań parami w obrębie jednego rzędu dla każdej wewnętrznej subtabeli. Testy (INT vs. LOC) 
wykonano dla każdej z czterech kategorii orientacji dydaktyczno-badawczej. Odpowiednio, tak jak poprzednio, dla każdej pary o różnicy frakcji znacznie różniącej się od zera, większa kategoria pojawia się w ostatniej kolumnie (tabela 13).

Silniejsza orientacja na rolę badawczą wśród internacjonalistów jest statystycznie istotna, podobnie jak orientacja na rolę dydaktyczną wśród miejscowych $(\mathrm{p}<0,001)$. Innymi słowy internacjonaliści cenią badania bardziej niż miejscowi. Pierwszoplanowe zainteresowanie kształceniem praktycznie wyklucza polskich naukowców z klasy internacjonalistów; odsetek internacjonalistów zainteresowanych przede wszystkim kształceniem wynosi 1,1\%. Jednak inaczej niż w przypadku literatury dotyczącej konkurencji między dydaktyką a badaniami (zob. Fox 1992; Ramsden 1994; Stephan 2012; Stephan i Levin 1992), 18,6\% osób zainteresowanych „zajęciami dydaktycznymi i badaniami naukowymi, ze wskazaniem na pierwsze" było internacjonalistami. Ponad 80\% internacjonalistów było zorientowanych na badania naukowe w porównaniu z około $60 \% \mathrm{w}$ przypadku miejscowych. W Polsce orientacja na badawczą rolę akademicką jest istotnym wskaźnikiem bycia internacjonalistą, natomiast orientacja dydaktyczna niemal wyklucza z przynależności do tej grupy. Na tej podstawie podtrzymujemy hipotezę 7 (choć głębsze analizy przeprowadzone z podziałem na klastry dyscyplin doprowadzily do niejednoznacznych wyników).

Tabela 13. Wyniki testu $z$ dla równości frakcji (wszystkie klastry dyscyplin lącznie)

\begin{tabular}{lcccc}
\hline & $\begin{array}{c}\text { P-value } \\
\text { International- } \\
\text { ists (INT) \% }\end{array}$ & $\begin{array}{c}\text { Locals } \\
\text { (LOC) \% }\end{array}$ & $\begin{array}{c}\text { Significantly } \\
\text { larger fraction }\end{array}$ \\
Primarily in teaching & 1,1 & 4,3 & $<0,001$ & LOC \\
In both, but leaning toward teaching & 18,6 & 34,9 & $<0,001$ & LOC \\
In both, but leaning toward research & 63,2 & 50,7 & $<0,001$ & INT \\
Primarily in research & 17,1 & 10,1 & $<0,001$ & INT \\
\hline
\end{tabular}

Objaśnienie: pytanie B2: „Proszę wskazać, czy w pracy akademickiej Pana(i) zainteresowania kierują się w stronę zajęć dydaktycznych czy prowadzenia badań?”.

\subsection{Wyniki badań - analiza wielowymiarowa}

4.4.1. Analiza oparta na modelu regresji logistycznej

4.4.1.1. Podejście modelowe (I) - predyktory współpracy międzynarodowej w badaniach naukowych

H8. Hipoteza dotycząca predyktorów - indywidualne predyktory bycia internacjonalistą sq̨ ważniejsze nïz predyktory instytucjonalne.

Jakie są predyktory bycia internacjonalistą? Co sprawia, że niektórzy polscy naukowcy mają większe szanse na współpracę z kolegami z zagranicy niż inni? Zmienną 
zależną w badaniach było umiędzynarodowienie kadry naukowej w dziedzinie badań („współpraca z naukowcami z zagranicy” w badaniach naukowych; pytanie D1/4; odpowiedź tak/nie). Analityczny model badania umiędzynarodowienia został opracowany na podstawie istniejącej literatury, zwłaszcza takich prac jak: Cummings i Finkelstein (2012), Rostan, Ceravolo i Metcalfe (2014), Finkelstein i Sethi (2014), Finkelstein, Walker i Chen (2013) oraz Abramo, D’Angelo i Solazzi (2011). Spośród czterdziestu dwóch wybranych cech osobowych i instytucjonalnych, zmienne niezależne zostały pogrupowane w zmienne indywidualne (36) i zmienne instytucjonalne (6). Poszczególne zmienne zostały następnie podzielone na sześć klastrów (tabela 14): cechy osobiste/demograficzne ( 15 zmiennych), umiędzynarodowienie i współpraca (11 zmiennych), socjalizacja do środowiska akademickiego (2 zmienne), zachowania akademickie (4 zmienne), produktywność badawcza (1 zmienna) oraz postawy akademickie i orientacja na role akademickie (3 zmienne).

Tabela 14. Umiędzynarodowienie w badaniach naukowych - zmienne w modelu (numery pytań ankietowych podano w nawiasach)

\section{Individual variables}

Personal/Demographics

Gender (F1)

Marital status (married or not) ( $\left.\mathrm{F}_{3}\right)$

Spouse employed (F4)

Spouse an academic ( $\left.\mathrm{F}_{5}\right)$

Spouse education level (F8-3)

Children under 18 at home (F6)

Age (F2)

Academic experience - years since first employment (A4)

$\mathrm{PhD}$ or lower degree (A1)

Habilitation degree (A1)

Full professorship (A1)

My academic discipline/field is important (B4)

My institution is important (B4)

Satisfaction with current job (B6)

Cluster of academic discipline (hard vs. soft) (A2)

Internationalization and collaboration

Emphasize international perspective or content in their courses $\left(\mathrm{C}_{4} / 5,1\right.$ and 2)

Most international students are currently international (C4/10, 1 and 2)

Teaching any courses abroad ( $\mathrm{C}_{5} / 2$, Yes/No)

Teaching any courses in a foreign language $\left(\mathrm{C}_{5} / 2\right.$, Yes/No)

Research primarily international in scope or orientation (D2/5, 1 and 2)

Employ primarily mother tongue in research (F12/1, Yes/No)

Publishing in a foreign country (D5/4, Yes/No, >0) 


\section{Individual variables}

Publishing in a foreign language (D5/1, Yes/No, >0)

Publishing works co-authored with colleagues located in other countries (D5/1, Yes/No, >0)

Spent at least two years in other countries since the award of their first degree (F13/3, Yes/No)

$\mathrm{PhD}$ earned in a foreign country $(\mathrm{A} 1 / 2 / 2)$.

Socialization to academia

Intensive faculty guidance (A3)

Research projects with faculty (A3)

Academic behaviors

Annualized mean weekly research hours (60\% in session, $40 \%$ not in session) (B1)

Annualized mean weekly teaching hours (60\% in session, 40\% not in session) (B1)

Annualized mean weekly admin. hours (60\% in session, 40\% not in session) (B1)

Annualized mean weekly total hours (60\% in session, $40 \%$ not in session) (B1)

Academic attitudes and role orientation

Research-oriented (only answer 4) (B2)

Scholarship is original research (B5)

Basic/theoretical research (D2)

Research productivity

Peer-reviewed articles (PRA) (D4/2 and D4/3)

\section{Institutional variables}

Institutional environment

Strong performance orientation (E4)

Institutional type (A9)

Research considered in personnel decisions (E6)

Availability of research funds (B3)

Supportive attitude of administration (E4)

Who has primary influence in establishing international linkages (individual/faculty) (E1)

Wszystkie zmienne jakościowe zostały poddane dychotomizacji. W celu wykrycia i wyeliminowania współliniowości wektora zmiennych niezależnych, zastosowano metodę odwrotnej macierzy korelacji. W jej wyniku nie stwierdzono istotnych zależności pomiędzy zmiennymi. Zmienne do modelu zostały wprowadzone przy użyciu metody eliminacji wstecznej w oparciu o kryterium Walda, dlatego w modelu uwzględniono tylko istotne zmienne. Model osiągnął zbieżność w 32 iteracji. Moc predykcyjna modelu (mierzona za pomocą $\mathrm{R}^{2}$ Nagelkerke'a) wyniosła 0,502. Wyniki dla modelu przedstawiono w tabeli 15 . 
Tabela 15. Iloraz szans oszacowany dla regresji logistycznej bycia internacjonalistą w badaniach naukowych - predyktory prowadzenia współpracy z kolegami z zagranicy

\begin{tabular}{|c|c|c|c|c|c|c|}
\hline & B & $\begin{array}{l}\text { Standard } \\
\text { Error }\end{array}$ & Wald & P-value & $\operatorname{Exp}(B)$ & DIAG \\
\hline Gender & & & & & & 1,18 \\
\hline Spouse employed & & & & & & 1,253 \\
\hline Spouse an academic & & & & & & 1,114 \\
\hline Spouse education level & & & & & & 1,106 \\
\hline Children under 18 at home & & & & & & 1,119 \\
\hline Age & & & & & & 2,16 \\
\hline Habilitation degree & & & & & & 1,533 \\
\hline Full professorship & 2,182 & 0,672 & 10,528 & $0,001^{* * *}$ & 8,862 & 2,039 \\
\hline My academic discipline/field is important & & & & & & 1,083 \\
\hline My institution is important & & & & & & 1,19 \\
\hline Satisfaction with current job & & & & & & 1,187 \\
\hline Intensive faculty guidance? & & & & & & 1,104 \\
\hline Research projects with faculty? & & & & & & 1,143 \\
\hline Annualized mean weekly research hours & 0,060 & 0,022 & 7,176 & $0,007^{* *}$ & 1,062 & 2,601 \\
\hline Annualized mean weekly teaching hours & & & & & & 1,448 \\
\hline Annualized mean weekly admin. hours & & & & & & 1,492 \\
\hline Annualized mean weekly total hours & & & & & & 2,987 \\
\hline Research-oriented & & & & & & 1,129 \\
\hline Scholarship is original research & & & & & & 1,082 \\
\hline Basic/theoretical research & & & & & & 1,148 \\
\hline Strong performance orientation & & & & & & 1,071 \\
\hline Institutional type & & & & & & 1,237 \\
\hline Research considered in personnel decisions & & & & & & 1,152 \\
\hline Availability of research funds & & & & & & 1,088 \\
\hline Supportive attitude of administration & & & & & & 1,09 \\
\hline $\begin{array}{l}\text { Who has primary influence in establishing } \\
\text { international linkages (individual/ faculty) }\end{array}$ & 1,230 & 0,491 & 6,286 & $0,012^{*}$ & 3,421 & 1,083 \\
\hline $\begin{array}{l}\text { Emphasize international perspective or con- } \\
\text { tent in their courses }\end{array}$ & & & & & & 1,143 \\
\hline Teaching any courses abroad & & & & & & 1,231 \\
\hline Teaching any courses in a foreign language & 1,048 & 0,464 & 5,111 & $0,024^{*}$ & 2,853 & 1,305 \\
\hline $\begin{array}{l}\text { Research primarily international in scope } \\
\text { or orientation }\end{array}$ & 1,546 & 0,441 & 12,270 & $0,000^{* * *}$ & 4,692 & 1,31 \\
\hline Employ primarily mother tongue in research & & & & & & 1,32 \\
\hline Publishing in a foreign country & & & & & & 2,595 \\
\hline Publishing in a foreign language & & & & & & 2,387 \\
\hline $\begin{array}{l}\text { Publishing works co-authored with colleagues } \\
\text { located in other countries }\end{array}$ & 1,303 & 0,586 & 4,948 & $0,026^{*}$ & 3,680 & 1,589 \\
\hline $\begin{array}{l}\text { Spent at least two years in other countries } \\
\text { since the award of their first degree }\end{array}$ & & & & & & 1,314 \\
\hline
\end{tabular}




\begin{tabular}{|c|c|c|c|c|c|c|}
\hline & B & $\begin{array}{l}\text { Standard } \\
\text { Error }\end{array}$ & Wald & P-value & $\operatorname{Exp}(B)$ & DIAG \\
\hline $\mathrm{PhD}$ earned in a foreign country & & & & & & 1,086 \\
\hline Hard scientist & 1,110 & 0,480 & 5,348 & $0,021^{*}$ & 3,034 & 1,488 \\
\hline Peer-reviewed articles (PRA) & & & & & & 3,14 \\
\hline Constant & $-3,246$ & 0,740 & 19,246 & $0,000^{* * *}$ & 0,039 & \\
\hline
\end{tabular}

Objaśnienie: w ostatniej kolumnie przedstawiono wartości głównej przekątnej odwróconej macierzy korelacji.

Sześć zmiennych indywidualnych i jedna zmienna instytucjonalna okazały się statystycznie istotne: posiadanie tytułu profesora zwyczajnego i bycie naukowcem w twardych dziedzinach, uśrednione tygodniowe godziny poświęcone na pracę naukową, nauczanie dowolnych przedmiotów w języku obcym, badania przede wszystkim o charakterze międzynarodowym lub o orientacji międzynarodowej, publikacje pisane wspólnie z kolegami z innych krajów oraz indywidualni naukowcy odpowiedzialni za utrzymywanie kontaktów międzynarodowych. Wszystkie pozostałe zmienne były statystycznie nieistotne według zastosowanego kryterium doboru zmiennych. Piastowanie stanowiska profesora zwyczajnego okazało się silnym predyktorem $(\operatorname{Exp}(B)=8,862)$, prawie dziewięciokrotnie zwiększając szanse na bycie internacjonalistą w stosunku do osób niebędących profesorami zwyczajnymi (przy innych predyktorach na stałym poziomie, ceteris paribus). W przypadku czasu poświęconego na badania tygodniowo, wzrost o jedną jednostkę (tj. o 1 godzinę) zwiększa szanse średnio o około 6,2 \% (ceteris paribus). Szanse rosły również wyraźnie wraz z kształceniem w obcym języku $(\operatorname{Exp}(B)=$ $2,853)$ i wydawaniem międzynarodowych publikacji współautorskich $(\operatorname{Exp}(B)=3,034)$.

Co ważne, w kontekście dotychczasowej literatury dotyczącej międzynarodowej współpracy badawczej, statystycznie nieistotne zmienne w klastrze cech osobistych i demograficznym obejmowały płeć, małżonka i rodzinę, wiek, a także przywiązanie do własnej dyscypliny i instytucji. We wcześniejszych badaniach przeprowadzanych w innych krajach stwierdzono, że bycie kobietą jest na ogół skorelowane z mniejszą intensywnością współpracy międzynarodowej w nauce (Fox et al. 2016; Abramo, D’Angelo i Murgia 2013), podobnie jak posiadanie dzieci w wieku szkolnym (Kyvik i Teigen 1996; Ackers 2008). W Polsce dopiero osiągnięcie szczytu kariery akademickiej (profesura zwyczajna) zwiększa szanse na współpracę międzynarodową w dziedzinie badań naukowych; ani posiadanie doktoratu, ani habilitacji nie wpływają istotnie na bycie internacjonalistą. Innymi słowy międzynarodowa współpraca badawcza jest silnie skorelowana z wysokimi osiągnięciami naukowymi (prowadzącymi do uzyskania tytułu profesora zwyczajnego; tytuł profesora zwyczajnego jako zmienna binarna jest skorelowany z produktywnością). Wiek nie jest statystycznie istotnym predyktorem; tym samym profesorowie, a nie naukowcy w starszym wieku, częściej angażują się we współpracę międzynarodową 
(ilościowe i jakościowe podejście międzypokoleniowe do polskiej kadry akademickiej, zob. Kwiek 2017). Podsumowując, hipoteza 8 została potwierdzona.

\subsubsection{Podejście modelowe (II): Jak umiędzynarodowienie w nauce wpływa na produktywność badawczą?}

H9. Hipoteza dotycząca typu produktywności badawczej - różne wymiary umiędzynarodowienia sq istotnie skorelowane z różnymi miarami produktywności.

Podejście modelowe zostało również wykorzystane do zbadania, w jaki sposób zmienne ogólne i zmienne związane $\mathrm{z}$ umiędzynarodowieniem (w kształceniu i badaniach) wpływają na różne aspekty produktywności. Jako miary produktywności, zmienne zależne obejmowały publikacje PRA, PRAE, IC-PRAE i ENG-PRAE. Zmienne niezależne związane z produktywnością obejmowały płeć, wiek, typ instytucjonalny (odniesienie - akademia), stopień lub tytuł naukowy (odniesienie - doktorat) i obszar nauki (odniesienie - nauki humanistyczne, HUM). Natomiast zmienne niezależne dotyczące umiędzynarodowienia obejmowały między innymi odpowiedzi na następujące stwierdzenia: „na Pan(i) zajęciach dydaktycznych zwraca się uwagę na międzynarodowy aspekt przekazywanych treści” $\left(\mathrm{C}_{4} / 5,1\right.$ i 2$)$, „,w prowadzonych badaniach współpracuje Pan(i) z kolegami z zagranicy” (D1/4, tak/nie), „obecnie większość studentów studiów magisterskich oraz doktoranckich to studenci zagraniczni” (C4/10, 1 i 2), „,nauczanie jakichkolwiek zajęć za granicą” ( $\mathrm{C}_{5} / 2$, tak/nie), „zajęcia dydaktyczne w języku innym niż wykładowy w Pana(i) uczelni” ( $55 / 2$, tak/nie), ,badania międzynarodowe - zarówno gdy chodzi o ich zakres, jak i przedmiot” (D2/5, 1 i 2), ,język ojczysty jako główny język w prowadzonych badaniach" (F12/1, tak/nie) (zob. tabelę 16). W tabeli tej przedstawiono wyniki analiz regresji liniowej z modelami dla każdego z czterech typów produktywności (produktywności według wskaźnika PRA, IC-PRA, ENG-PRA i PRAE). Dla każdego typu produktywności wyodrębniono trzy modele: wszyscy naukowcy (ALL), internacjonaliści (INT) i miejscowi (LOC). W sumie oszacowano dwanaście modeli, dla każdego z nich przedstawiono współczynniki regresji i istotność.

W pierwszym modelu regresji produktywności (zmienna zależna - PRA), dla wszystkich naukowców (model 1), ogólne zmienne niezależne istotnie związane z produktywnością to: wiek, stopień naukowy, tytuł profesora zwyczajnego i nauki przyrodnicze; istotne zmienne niezależne związane z umiędzynarodowieniem to: publikowanie w obcym kraju, publikowanie w języku obcym i współautorstwo międzynarodowe. Model wyjaśnia około $41 \%$ wariancji $\left(\mathrm{R}^{2}=0,409\right)$. Podsumowując, starsi naukowcy produkują mniej prac, a wszystkie zmienne związane z umiędzynarodowieniem zwiększają ich produktywność.

W drugim modelu regresji produktywności (ta sama zmienna zależna - PRA) dla internacjonalistów (model 2) ogólnymi zmiennymi niezależnymi istotnie związanymi 
z produktywnością okazały się: wiek, stopień naukowy, tytuł profesora zwyczajnego oraz dwie zmienne niezależne powiązane z umiędzynarodowieniem, a więc: publikowanie w języku obcym i międzynarodowe współautorstwo publikacji. Podobnie jak w modelu 1, istniała istotna ujemna korelacja pomiędzy wiekiem a produktywnością. Model ten wyjaśnia prawie $40 \%$ wariancji $\left(\mathrm{R}^{2}=0,388\right)$. I wreszcie w modelu regresji produktywności (zmienna zależna - PRA) dla miejscowych (model 3) istotne okazały się tylko dwie zmienne niezależne (obie związane z umiędzynarodowieniem): publikowanie w obcym kraju i publikowanie w języku obcym $\left(\mathrm{R}^{2}=0,315\right)$.

W modelach 4-6 IC-PRA było zmienną zależną, w modelach 7-9 zmienną zależną było ENG-PRA, a w modelach 10-12 PRAE było zmienną zależną - z oddzielnymi modelami dla wszystkich naukowców, internacjonalistów i miejscowych.

Analizy prowadzą do kilku interesujących uogólnień i wskazują na kilka wyjątków. Płeć nie jest istotnym predyktorem w żadnym modelu dla jakiejkolwiek zmiennej zależnej związanej z produktywnością. Wiek jako zmienna niezależna nie jest skorelowany z produktywnością dla miejscowych w żadnym z czterech grup modeli regresji, ani dla trzech typów naukowców w przypadku ekwiwalentów artykułów jako zmiennej zależnej (modele 10-12). Można to wyjaśnić faktem, że miejscowi są bardziej przywiązani do tradycyjnych (i ogólnie mniej konkurencyjnych) sposobów publikowania książek i książek redagowanych. Habilitacja i profesura są istotnie skorelowane ze wszystkimi naukowcami i internacjonalistami (ale nie z miejscowymi), być może wyjaśniając, dlaczego współpraca międzynarodowa jest silnie skorelowana z produktywnością mierzoną za pomocą wszystkich zmiennych zależnych (PRA, IC-PRA, ENG-PRA i PRAE). W przypadku miejscowych korelacja dotyczy tylko ekwiwalentów artykułów, co oznacza, że miejscowi przesuwają się po drabinie stopni naukowych i tytułów poprzez tradycyjne sposoby publikowania (książki i książki redagowane), a nie artykuły. Międzynarodowa treść lub orientacja w kształceniu i kształcenie studentów międzynarodowych jako zmienne niezależne dotyczące umiędzynarodowienia (związane z kształceniem) nie są skorelowane z produktywnością. Natomiast kształcenie w języku obcym jest negatywnie skorelowane z produktywnością w modelach ENG-PRA i PRAE. Potwierdza to tradycyjny kompromis między nauczaniem/badaniami i ich konkurencyjność, a nie uzupełnianie się (Fox 1992) w polskiej akademii. Co ciekawe, wśród zmiennych niezależnych związanych z umiędzynarodowieniem, ani długoterminowy pobyt za granicą, ani zagraniczny doktorat nie są skorelowane z produktywnością, co potwierdza wcześniejsze ustalenia dotyczące mobilności, współpracy i produktywności (Ackers 2008). Tylko w przypadku modelu IC-PRA dla miejscowych produktywność rośnie wraz z długoterminowym pobytem za granicą (średnio o 0,7 artykułu recenzowanego napisanego we współpracy międzynarodowej w trzyletnim okresie referencyjnym). Można zatem przyjąć prawdziwość hipotezy 9. 


\section{Podsumowanie, dyskusja i wnioski}

W ramach profesji akademickiej międzynarodowa współpraca naukowa odgrywa coraz bardziej stratyfikującą rolę. Naukowcy, którzy nie współpracują na arenie międzynarodowej, mogą tracić dzisiaj więcej niż kiedykolwiek wcześniej, ponieważ wzorce finansowania i modele prestiżu ulegają szybkim zmianom, zdecydowanie faworyzując internacjonalistów w badaniach. Pionowa stratyfikacja instytucji (znajdująca odzwierciedlenie w krajowych i międzynarodowych systemach rankingowych a ostatnio w Polsce w programie Inicjatywa Doskonałości - Uczelnia Badawcza) oraz naukowców (wyrażająca się w zmieniających się wymaganiach dotyczących rozwoju kariery naukowej) coraz silniej przekształca krajowe systemy nauki w Europie Środkowej i Wschodniej (Antonowicz i in. 2017; Antonowicz 2016; Dakowska 2015). W miarę jak postępuje umasowienie szkolnictwa wyższego, następuje jego stratyfikacja, zarówno na poziomie instytucjonalnym, jak i indywidualnym.

Na poziomie indywidualnym rosnące nierówności wynikają przede wszystkim z rosnącej stratyfikacji (czyli postępującego rozwarstwienia) pod względem osiągnięć naukowych, co - jak pokazujemy tu szczegółowo - jest ściśle związane z rosnącą stratyfikacją pod względem umiędzynarodowienia badań naukowych. Inne formy stratyfikacji podkopujące jednorodność tradycyjnej wspólnoty akademickiej dotyczą wynagrodzeń, władzy akademickiej, ról akademickich, wieku, a także wzorców publikowania, płci i dostępu do finansowania badań (zob. poszczególne rozdziały w naszej najnowszej monografii poświęconej europejskiej kadrze akademickiej Kwiek 2019). Środowisko naukowe jest silnie podzielone pod względem osiągnięć naukowych, dochodów, stanowisk akademickich, płci, kohorty wiekowej, rozkładu czasu poświęcanego na kształcenie i badania, możliwości finansowania badań oraz pod kątem dostępu do prestiżowych czasopism. Stratyfikację globalnej społeczności naukowej wyraźnie warunkują badania naukowe, a w jej centrum znajduje się ich umiędzynarodowienie.

Część naukowców wyłania się z powyższych analiz jako wyraźnie bardziej umiędzynarodowiona niż inni, a podział na internacjonalistów i miejscowych w badaniach przenika polskie środowisko naukowe. Procesy nazwane przez nas „skumulowaną przewagą z racji umiędzynarodowienia” i „skumulowaną stratą z racji braku umiędzynarodowienia" zachodzą jednocześnie, dzieląc środowisko naukowe pod względem prestiżu, uznania i dostępu do konkurencyjnego finansowania badań. Umiędzynarodowienie $\mathrm{w}$ badaniach naukowych jest potężną siłą rozwarstwiającą nie tylko instytucje (powodującą ich pionowe zróżnicowanie), ale także ich wydziały (doprowadzając do segmentacji poziomej). Wysoce umiędzynarodowione instytucje, wydziały, grupy badawcze i poszczególni naukowcy coraz częściej zderzają się w polskim systemie - i w innych „nadrabiających zaległości” systemach nauki - z ich słabo umiędzynarodowionymi odpowiednikami. 


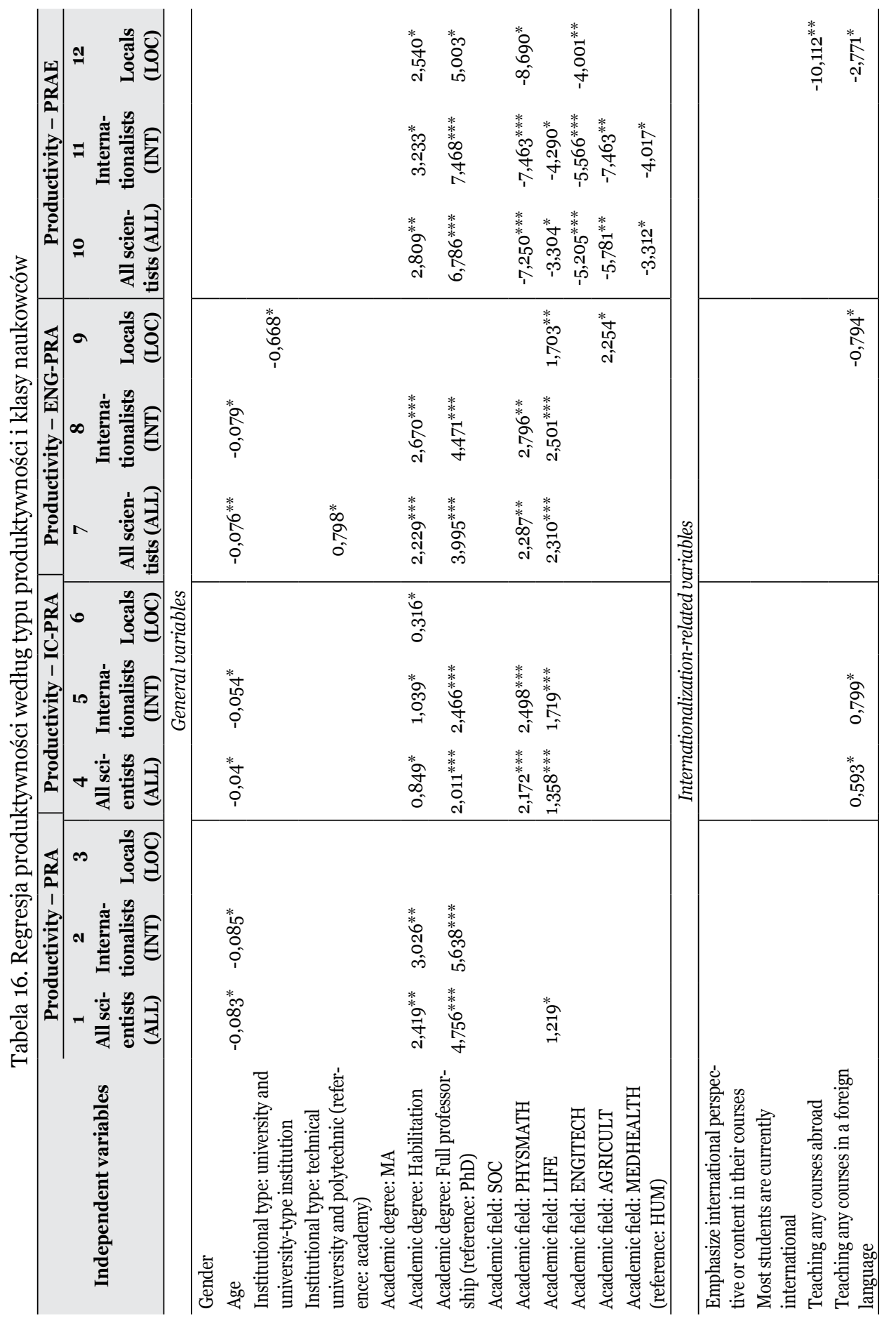




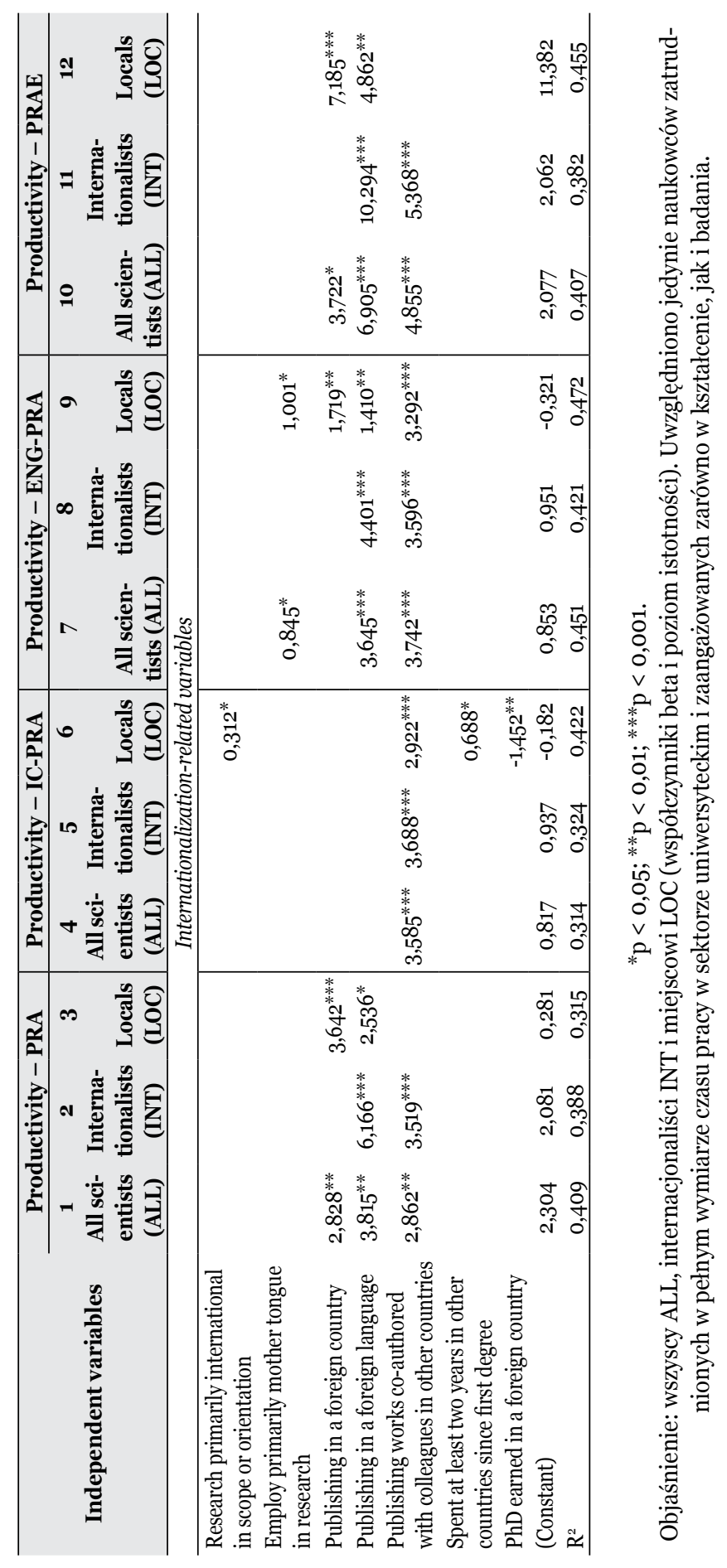


W przeprowadzonych badaniach przetestowano dziewięć hipotez na dużej próbie polskich naukowców ze wszystkich dziedzin ( $\mathrm{n}=3704$ zwrócone kwestionariusze). Hipotezy badawcze, dzięki wykorzystaniu danych ankietowych, a nie danych bibliometrycznych, zdecydowanie wykraczały poza tradycyjnie badane czynniki współpracy międzynarodowej i obejmowały płeć, wiek i staż naukowy, dziedzinę nauki, współpracę krajową, produktywność badawczą, rozkład czasu pracy, orientację na rolę akademicką, a także, przy zastosowaniu podejścia wielowymiarowego, indywidualne i instytucjonalne predyktory bycia internacjonalistą oraz wpływ różnych typów umiędzynarodowienia na produktywność mierzoną kilkoma równoległymi miarami. Jako jasno określona subpopulacja polskich naukowców $(51,4 \%)$, tytułowi internacjonaliści wyłaniają się z naszych badań jako odmienny typ kadry akademickiej. Wyniki naszych badań potwierdzają, że znacznie różnią się oni od tytułowych miejscowych, czyli naukowców nie współpracujących z kolegami z innych krajów w badaniach naukowych.

Internacjonaliści to przede wszystkim mężczyźni, a różnica między płciami niesie ze sobą poważne konsekwencje dla polityki kadrowej. Jeśli (1) sukces naukowców w globalnym, rozwarstwionym środowisku akademickim opiera się na osiągnięciach badawczych, a nie na sukcesach w kształceniu czy pracy administracyjnej, oraz jeśli (2) produktywność jest silnie skorelowana ze współpracą międzynarodową to kobiety naukowcy, będące rzadziej internacjonalistami, prawdopodobnie ponoszą dzisiaj większe straty niż kiedykolwiek wcześniej pod względem dostępu do finansowania i skumulowanego prestiżu naukowego. Dotyczy to zwłaszcza systemów niedofinansowanych, takich jak polski, w których konkurencja jest silniejsza, a „skumulowana strata" (Cole i Cole 1973: 146) w większym stopniu powoduje, że biedni stają się nieproporcjonalnie biedniejsi, zgodnie z efektem Mateusza w nauce.

Stratyfikacja kadry akademickiej pod kątem umiędzynarodowienia badań, w ramach której współpraca międzynarodowa prowadzi do większej liczby publikacji i lepszych wskaźników cytowalności, okazuje się bardziej szkodliwa dla kobiet naukowców niż dla mężczyzn naukowców. W Polsce większość kobiet naukowców stanowią miejscowi (55\%), a większość mężczyzn - internacjonaliści (56\%). W związku z tym awans kobiet na drabinie akademickiej opartej o osiągnięcia czysto naukowe będzie z czasem prawdopodobnie dłuższy i trudniejszy, a dostęp do coraz bardziej konkurencyjnych funduszy indywidualnych na badania - coraz bardziej utrudniony. Chyba że, jak w wielu krajach, powstaną programy skierowane szczególnie do kobiet, zwłaszcza w obszarach STEM.

Internacjonaliści są starsi, dysponują większym doświadczeniem akademickim i mają wyższe stopnie naukowe oraz zajmują wyższe stanowiska. W systemach ubogich w zasoby ('środki, ludzie, infrastruktura i czas), takich jak Polska, internacjonaliści stanowią większość kadry uczelnianej dopiero w przedziale wiekowym powyżej 50 lat, wśród osób z ponad dwudziestoletnim doświadczeniem akademickim, ze stopniem doktora habilitowanego i profesurą tytularną. Pojawiający się wzorzec jest jasny 
(i statystycznie istotny); umiędzynarodowienie badań osiąga wysoki poziom charakterystyczny dla systemów bogatych w zasoby tylko dla wąskiej klasy profesorów zwyczajnych (74,6\% z nich to internacjonaliści). Istnieje również silne zróżnicowanie interdyscyplinarne; udział internacjonalistów sięga 80\% w klastrze nauk fizycznych i matematycznych w porównaniu z zaledwie $36,3 \%$ w zakresie nauk społecznych i tylko dla połowy profesorów zwyczajnych w naukach społecznych w porównaniu z ponad 90\% w naukach fizycznych i matematycznych. Zgodnie z wcześniejszymi badaniami (Kyvik i Larsen 1997; Piro, Aksnes i Rørstad 2013), obecne wyniki potwierdzają, że umiędzynarodowienie jest silnie uzależnione od dziedziny nauki. Udział młodych internacjonalistów z pewnością rośnie dzięki nowym programom badawczym finansowanym przez Narodowe Centrum Nauki, wysoce konkurencyjnym i dedykowanym specjalnie dla młodych naukowców (Bieliński i Tomczyńska 2018). Jednak całkowity budżet NCN jest jednak stanowczo zbyt niski.

Współpraca międzynarodowa nie odbywa się kosztem współpracy krajowej; w rzeczywistości internacjonaliści współpracują wewnątrz kraju na masową skalę, chociaż ten wymiar współpracy badawczej był dotąd rzadko badany (wyjątki to Sooryamoorthy 2014 oraz Jeong, Choi, i Kim 2011). Tylko 20,5\% internacjonalistów nie współpracuje w kraju, z nieznanych powodów, które mogą obejmować zarówno brak czasu, brak środków finansowych, jak i ograniczone możliwości wspólnego publikowania w skali międzynarodowej. Na drugim biegunie tylko połowa miejscowych współpracuje w kraju, to znaczy połowa tych, którzy nie współpracują międzynarodowo, również nie współpracuje w kraju (przy silnym zróżnicowaniu dziedzinowym). W naukach humanistycznych i społecznych 63,3\% miejscowych nie współpracuje w skali krajowej; oznacza to, że w klastrze miękkich dyscyplin akademickich dominuje model „samotnego uczonego”, który nie prowadzi wspólnych badań ani z naukowcami z Polski, ani ze świata.

Jeśli chodzi o produktywność badawczą, internacjonaliśsi sześciokrotnie częściej niż miejscowi wydają publikacje we współautorstwie zagranicznym; wśród miejscowych międzynarodowe współautorstwo publikacji jest zjawiskiem marginalnym i wynosi 2,1\% (w porównaniu z 13,8\% w przypadku internacjonalistów). We wszystkich klastrach internacjonaliści konsekwentnie wydają ponad 90\% międzynarodowych publikacji współautorskich, a w klastrach PHYSMATH, SOC i LIFE wskaźnik ten osiąga 97-99,9\%. W tych klastrach brak współpracy międzynarodowej oznacza w praktyce brak współautorskich publikacji międzynarodowych.

Naukowcy z dziedzin twardych, którzy nie współpracują na arenie międzynarodowej, deklarują, że tylko 3,2\% ich publikacji to publikacje powstałe we współpracy międzynarodowej; w dziedzinach miękkich odsetek ten wynosi zaledwie 1,9\%. Wynika z tego, że międzynarodowe współautorstwo na dużą skalę jest na ogół tworzone wyłącznie przez internacjonalistów na podstawie międzynarodowej współpracy badawczej. Tylko znikomy ułamek publikacji powstających w ramach nauki izolowanej na poziomie krajowym może być 
publikowany we współpracy na poziomie międzynarodowym, a publikacje współtworzone na poziomie międzynarodowym zależą wyłącznie od współpracy z kolegami z zagranicy.

Nasze narzędzie badawcze ułatwiło porównanie produktywności internacjonalistów i miejscowych w odniesieniu do szerokiego wachlarza typów publikacji. We wszystkich przypadkach internacjonaliści okazali się bardziej produktywni niż miejscowi w statystycznie istotnym zakresie $(\mathrm{p}<0,001)$. Internacjonaliści wyłaniają się z tego badania jako o wiele bardziej produktywni pod względem międzynarodowych publikacji współautorskich: reprezentują 2320\% produktywności miejscowych w przypadku artykułów recenzowanych i 1600\% w przypadku odpowiedników artykułów recenzowanych dla tego typu publikacji.

Analizy regresji wielorakiej pokazały, że płeć nie jest czynnikiem determinującym w żadnym modelu ze zmienną zależną związaną z produktywnością. Wiek jako zmienna niezależna jest ujemnie skorelowany z produktywnością miejscowych i jest ujemnie skorelowany dla wszystkich naukowców i dla internacjonalistów. Habilitacja i profesura są dodatnio skorelowane z wyższą produktywnością dla wszystkich naukowców i dla internacjonalistów, ale nie dla miejscowych. Nic dziwnego, że w kontekście polskim zmienne niezależne związane z kształceniem i umiędzynarodowieniem (takie jak treści międzynarodowe w kształceniu, kształcenie studentów zagranicznych czy kształcenie w języku obcym) były ujemnie skorelowane z produktywnością. Tradycyjna konkurencja między kształceniem i badaniami w polskiej akademii została potwierdzona statystycznie. Wśród zmiennych niezależnych, związanych z umiędzynarodowieniem, na ogół ani długoterminowe pobyty za granicą, ani doktorat zdobyty za granicą nie były istotnie skorelowane z produktywnością, co potwierdza wcześniejsze ustalenia dotyczące mobilności, współpracy i produktywności (Ackers 2008).

Podsumowując, nasze badania wskazują na stratyfikującą moc współpracy międzynarodowej wobec środowiska akademickiego w systemie nauki, który przechodzi od głębokiego niedofinansowania i silnego zaangażowania krajowego do coraz lepszego, ale wysoce selektywnego finansowania i dużego zaangażowania międzynarodowego. Internacjonaliści i miejscowi różnią się między sobą: pracują, myślą o swojej roli akademickiej, publikują i współpracują w odmienny sposób, a także napotykają na odmienne bariery w zakresie awansu akademickiego i pozyskiwania środków finansowych na badania. Równowaga ilościowa między internacjonalistami i miejscowymi w dziedzinie badań z pewnością będzie znikać, a w powstającym systemie, który w coraz większym stopniu koncentruje się na finansowaniu umiędzynarodowienia badań, należy spodziewać się rosnącej przewagi ilościowej pierwszych kosztem drugich.

Implikacje naszych badań dla polityki naukowej są jednoznaczne. Jeśli globalna sieć nauki wyłania się, ponieważ naukowcy „łączą się ze sobą na zasadzie wzajemnego partnerstwa, a proces preferencyjnego przywiązania wybiera określone osoby do coraz bardziej elitarnego kręgu" (Wagner 2018: x), to miejscowi w każdym kraju (z ewentualnym wyjątkiem USA) są stopniowo wykluczani z trwającej globalnej transformacji 
nauki. Polska, jako mocno niedofinansowany uczestnik globalnej nauki, musi rozważyć dokonanie radykalnych zmian w strukturze kadry naukowej. Z tego względu, w sektorze uczelni badawczych, miejscowi powinni być $\mathrm{w}$ coraz większym stopniu zastępowani przez internacjonalistów, czy to przez nowych, młodszych naukowców, czy też przez starszych naukowców, którzy przekształcają się w internacjonalistów wraz z nowymi możliwościami współpracy międzynarodowej. Obecny podział 50:50, w którym tylko połowa naukowców współpracuje na arenie międzynarodowej w dziedzinie badań, musi stopniowo ulegać zmianie. Trzydziestoletni okres transformacji postkomunistycznej (1989-2019) dobiegł końca i tłumaczenie niepowodzenia reform sektora nauki akademickiej i jego niedofinansowania za pomocą argumentów historycznych jest z dzisiejszej perspektywy globalnej nauki nie do przyjęcia. Coraz częściej naukowcy w świecie wybierają wspólną, sieciową naukę, która jest zakorzeniona lokalnie (poprzez kształcenie i instytucje) i finansowana na szczeblu krajowym - ale nastawiona na globalną współpracę badawczą (zob. Kwiek 2020). Polska polityka naukowa musi na te zmiany reagować, promując przekształcanie kadry naukowej i pogłębianie jej pionowej stratyfikacji oraz zapewniając radykalnie wyższe finansowanie międzynarodowej współpracy naukowej. Tylko w ten sposób możemy uniknąć pełzającej izolacji na kluczowym dzisiaj poziomie nauki globalnej.

\section{Podziękowania}

Tekst jest tłumaczeniem pracy „Internationalists and Locals: International Research Collaboration in Resource-Poor Systems" złożonej w Scientometrics. Autor wyraża wdzięczność za wsparcie otrzymane w projekcie MNISW Dialog (0022/DLG/2019/10). Istotny wkład do prowadzonych badań wniósł dr Wojciech Roszka z Uniwersytetu Ekonomicznego w Poznaniu, członek zespołu badawczego Dialog, za co jestem mu ogromnie wdzięczny.

\section{Literatura}

Abrahamson, M. (1965). Cosmpolitanism, Dependence-Identification, and Geographical Mobility. Administrative Science Quarterly 10: 98-106.

Abramo, G., D’Angelo, C.A., Di Costa, F. (2019). A gender analysis of top scientists' collaboration behavior: evidence from Italy. Scientometrics. Publikacja online: 30 maja 2019.

Abramo, G., D’Angelo, C.A., Murgia, G. (2013). Gender Differences in Research Collaboration. Journal of Informetrics 7: 811-822.

Abramo, G., D’Angelo, C.A., Solazzi, M. (2011a). The Relationship between Scientists' Research Performance and the Degree of Internationalization of Their Research. Scientometrics 86. 629-643.

Abramo, G., D’Angelo, C.A. i Murgia, G. (2014). Variation in Research Collaboration Patterns across Academic Ranks. Scientometrics 98(3), 2275-2294. 
Abramo, G., D’Angelo, C.A., Di Costa, F. (2018). The collaboration behavior of top scientists. Scientometrics. Publikacja online: 29 listopada 2018.

Abramo., G., D'Angelo, C.A., Solazzi, M. (2011b). Are researchers that collaborate more at the international level top performers? An investigation on the Italian university system Journal of Informetrics. 5: 204-213.

Abramo., G., D’Angelo, C.A., Murgia, G. (2016). The combined effect of age and seniority on research performance of full professors. Science and Public Policy 43(3): 301-319.

Ackers, L. (2008). Internationalization, mobility and metrics: A new form of indirect discrimination? Minerva 46: 411-435.

Aksnes, D.W., Piro, F.N., Rørstad, K. (2019). Gender gaps in international research collaboration: a bibliometric approach. Scientometrics. Publikacja online: 13 czerwca 2019.

Antonowicz, D. (2016). Digital players in an analogue world: Higher education in Poland in the post-massification era. W: B. Jongbloed i H. Vossensteyn (red.), Access and expansion post-massification. Opportunities and barriers to further growth in higher education participation (ss. 63-81). London: Routledge.

Antonowicz, D., Kwiek, M. i Westerheijden, D.F. (2017). The government response to the private sector expansion in Poland. W: H. de Boer, J. File, J. Huisman, M. Seeber, M. Vukasovic i D.F. Westerheijden (red.), Policy analysis of structural reforms in higher education (ss. 119-138). Dordrecht: Springer.

Arimoto, A. (2011). Japan: Effects of Changing Governance and Management on the Academic Profession. W: W. Locke, W.K. Cummings, D. Fisher (red.), Changing Governance and Management in Higher Education. The Perspectives of the Academy (ss. 281-319). Dordrecht: Springer.

Bentley, P.J. (2015). Cross-country differences in publishing productivity of academics in research universities. Scientometrics 102(1), 865-883.

Bieliński, J. i Tomczyńska, A. (2018). The Ethos of Science in Contemporary Poland. Minerva. Publikacja online: https://link.springer.com/article/10.1007/s11024-018-9365-1.

Bonaccorsi, A., Daraio, C. (2003). Age effects in scientific productivity. The case of the Italian National Research Council (CNR). Scientometrics 58(1): 49-90.

Bryman, A. (2012). Social Research Methods. $4^{\text {th }}$ Edition. Oxford: Oxford University Press.

Carvalho, T. (2017). The study of the academic profession - contributions from and to the sociology of professions. W: Huisman, J. i M. Tight (red.), Theory and method in higher education research. Bingley, UK: Emerald Group Publishing Limited, First edition, 59-76.

Cohen, L., Manion, L. i Morrison, K. (2011). Research methods in education. New York: Routledge. Cole, J.R. i Cole, S. (1973). Social stratification in science. Chicago: University of Chicago Press.

Costas, R., van Leeuwen, T.N, Bordons, M. (2010). A Bibliometric Classificatory Approach for the Study and Assessment of Research Performance at the Individual Level: the Effects of Age on Productivity and Impact. Journal of the American Society for Information Science and Technology 61(8): 1564-1581. 
Cummings, J.N., Kiesler, S. (2007). Coordination costs and project outcomes in multi-university collaborations. Research Policy 36: 1620-1634.

Dakowska, D. (2015). Between competition imperative and Europeanisaton: the case of higher education reform in Poland. Higher Education 69(1): 129-141.

Finkelstein, M. i Sethi, W. (2014). Patterns of Faculty Internationalization: A Predictive Model. W: F. Huang, M. Finkelstein i M. Rostan (red.), The Internationalization of the Academy. Changes, Realities and Prospects. Dordrecht: Springer. 237-258.

Finkelstein, M.J., Walker, E. i Chen, R. (2013). The American faculty in an age of globalization: predictors of internationalization of research content and professional networks. Higher Education 66: 325-340.

Finkelstein, M.J., Seal, R.K. i Schuster, J.H. (1998). The New Academic Generation. A Profession in Transformation. Baltimore: The Johns Hopkins University Press.

Fox, M.F. (1992). Research, teaching, and publication productivity. Mutuality versus competition in academia. Sociology of Education 65(4), 293-305.

Fox, M.F., Realff, M.L., Rueda, D.R. i Morn, J. (2006). International Research Collaboration Among Women Engineers: Frequency and Perceived Barriers, by Regions. Journal of Technology Transfer. Published online: 17 października 2016.

Gazni, A, Sugimoto, C.R i Didegah, F. (2012). Mapping World Scientific Collaboration: Authors, Institutions, and Countries. Journal of the American Society for Information Science and Technology 63(2): 323-335.

Georghiou, L. (1998). Global cooperation in research. Research Policy 27: 611-628.

Glaser, B.G. (1963). The Local-Cosmopolitan Scientist. The American Journal of Sociology 69, 249-259.

Godin, B. i Gingras, Y. (2000). Impact of Collaborative Research on Academic Science. Science and Public Policy 27(1). 65-73.

Gorelova, O. i Lovakov, A. (2016). Academic Inbreeding and Research Productivity of Russian Faculty Members. Working Papers. WP BRP 32/EDU/2016.

Gouldner, A. (1957). Cosmopolitans and Locals: Toward an Analysis of Latent Social Rules. Administrative Science Quarterly 2, 281-306.

Groves, R.M. (2006). Nonresponse Rates and Nonresponse Bias in Household Surveys. Public Opinion Quarterly 70(5), 646-675.

Guldbrandsen, M. i Smeby, J.-C. (2005). Industry funding and university professors' research performance. Research Policy 34, 932-950.

GUS (2011). Higher Education Institutions and Their Finances in 2010. Warsaw: GUS (Central Statistical Office).

Hibberts, M.R., Johnson, B. i Hudson, K. (2012). Common survey sampling techniques. W: L. Gideon, (red.), Handbook of survey methodology for the social sciences (ss. 53-74). Dordrecht: Springer.

Hoekman, J., Frenken, K. i Tijssen, R.J.W. (2010). Research collaboration at a distance: chnaging spatial patterns of scientific collaboration within Europe. Research Policy 39: 662-673. 
Huang, F., Finkelstein, M. i Rostan, M. (2014). The Internationalization of the Academy. Changes, Realities and Prospects. Dordrecht: Springer.

Jeong, S., Choi, J.Y. i Kim, J.-Y. (2011). The determinants of research collaboration modes: Exploring the effects of research and researcher characteristics on co-authorship. Scientometrics 89, 967-983.

Jeong, S., Choi, J.Y., Kim, J.-Y (2014). On the drivers of international collaboration: the impact of informal communication, motivation, and research resources. Science and Public Policy 41 (4): 520-531.

Jones, G.A., Gopaul, B., Weinrib, J., Metcalfe, A.S., Fisher, D., Gingras, Y., Rubenson, K. (2014). Teaching, Research, and the Canadian Professoriate. W: J.C. Shin, A. Arimoto, W.K. Cummings, U. Teichler (red.), Teaching and Research in Contemporary Higher Education. Systems, Activities and Rewards (ss. 335-355). Dordrecht: Springer.

Jung, J. (2014). Research Productivity by Career Stage among Korean Academics. Tertiary Education and Management Vol. 20(2). 85-105.

Jung, J., Kooij, R. i Teichler, U. (2014). Internationalization and the New Generation of Academics. W: F. Huang, M. Finkelstein i M. Rostan (red.), The Internationalization of the Academy. Changes, Realities and Prospects (ss. 207-236). Dordrecht: Springer.

Kwiek, M. (2012). Changing higher education policies: From the deinstitutionalization to the reinstitutionalization of the research mission in Polish universities. Science and Public Policy 35(5), 641-654.

Kwiek, M. (2015a). The internationalization of research in Europe. A quantitative study of 11 national systems from a micro-level perspective. Journal of Studies in International Education 19(2), 341-359.

Kwiek, M. (2015b). The unfading power of collegiality? University governance in Poland in a European comparative and quantitative perspective. International Journal of Educational Development 43, 77-89.

Kwiek, M. (2015c). Academic generations and academic work: Patterns of attitudes, behaviors and research productivity of Polish academics after 1989'. Studies in Higher Education 40(8), 1354-1376.

Kwiek, M. (2016a). The European research elite: A cross-national study of highly productive academics across 11 European systems. Higher Education 71(3), 379-397.

Kwiek, M. (2016b). From Privatization (of the Expansion Era) to De-privatization (of the Contraction Era). A National Counter-trend in a Global Context. W: S. Slaughter i B.J. Taylor (red.), Higher Education, Stratification, and Workforce Development. Competitive Advantage in Europe, the US and Canada (ss. 311-329). Dordrecht: Springer.

Kwiek, M. (2017). A generational divide in the Polish academic profession. A mixed quantitative and qualitative approach. European Educational Research Journal 17, 1-26.

Kwiek, M. (2018a). Academic top earners. Research productivity, prestige generation and salary patterns in European universities. Science and Public Policy 45(1). February 2018. 1-13. 
Kwiek, M. (2018b). International Research Collaboration and International Research Orientation: Comparative Findings About European Academics. Journal of Studies in International Education 22(2): 136-160.

Kwiek, M. (2018c). High Research Productivity in Vertically Undifferentiated Higher Education Systems: Who Are the Top Performers? Scientometrics 115(1). 415-462.

Kwiek, M. (2019). Changing European Academics: A Comparative Study of Social Stratification, Work Patterns and Research Productivity. London and New York: Routledge.

Kwiek, M. (2020). Międzynarodowa współpraca badawcza w Europie w świetle dużych danych i jej globalne konteksty. Nauka 1(2020).

Kwiek, M. i Szadkowski, K. (2018). Higher Education Systems and Institutions: Poland. W: International Encyclopedia of Higher Education Systems, red. Pedro N. Texteira i J.C. Shin, 1-20. Cham: Springer.

Kyvik, S. (1990). Age and scientific productivity. Differences between fields of learning. Scientometrics 19(1): 37-55.

Kyvik, S. i Aksnes, D.W. (2015). Explaining the increase in publication productivity among academic staff: A generational perspective. Studies in Higher Education 40, 1438-1453.

Kyvik, S., Larsen, I.M. (1997). The exchange of knowledge. A small country in the international research community. Science Communication 18(3). 238-264.

Kyvik, S., Teigen, M. (1996). Child Care, Research Collaboration, and Gender Differences in Scientific Productivity. Science, Technology, \& Human Values 21(1): 54-71.

Kyvik, S., Olsen, T.B. (2008). Does the aging of tenured academic staff affect the research performance of universities? Scientometrics. Vol. 76(3). 439-455.

Levin, S.G., Stephan, P.E. (1989). Age and research productivity of academic scientists. Research in Higher Education Vol. 30(5). 531-549.

Levin, S.G., Stephan, P.E. (1991). Research Productivity Over the Life Cycle: Evidence for Academic Scientists. The American Economic Review Vol. 81(1). 114-132.

Locke, W., Benion, A. (2011). The United Kingdom: Academic Retreat or Professional Renewal? W: W. Locke, W.K. Cummings, D. Fisher (red.), Changing Governance and Management in Higher Education. The Perspectives of the Academy (ss. 175-197). Dordrecht: Springer.

Luukkonen, T., Persson, O. i Sivertsen, G. (1992). Understanding Patterns of International Scientific Collaboration. Science, Technology, \& Human Values 17(1): 101-126.

Marquina, M. i Jones, G. (2015). Generational Change and Academic Work: An Introduction. Studies in Higher Education 40(8), 1349-1353.

Marquina, M., Yuni, J., Ferreiro, M. (2015). Generational Change in Argentine academic profession through the analysis of 'life courses'. Studies in Higher Education 40(8), 1392-1405.

McNeeley, S. (2012). Sensitive Issues in Surveys: Reducing Refusals While Increasing Reliability and Quality of Responses to Sensitive Survey Items. W: G. Lior Gideon (red.), Handbook of survey methodology for the social sciences (ss. 377-396). Dordrecht: Springer.

Melin, G. (2000). Pragmatism and self-organization: Research collaboration on the individual level. Research Policy 29: 31-34. 
Merton, R.K. (1973). The sociology of science: Theoretical and empirical investigations. Chicago: University of Chicago Press.

Ostrowicka, H. i Stankiewicz, L. (2018). The truths of business and the lies of academia: the order of discourse on higher education in Poland. Higher Education Research \& Development. On-line first: https://doi.org/10.1080/07294360.2018.1545746.

Piro, F.N., Aksnes, D.W. i Rørstad, K. (2013). A Macro Analysis of Productivity Differences Across Fields: Challenges in the Measurement of Scientific Publishing. Journal of the American Society for Information Science and Technology 64(2), 307-320.

Piro, F.N., Rørstad, K. i Aksnes, D.W. (2016). How does prolific professors influence on the citation impact of their university departments? Scientometrics 107(3), 941-961.

Ramsden, P. (1994). Describing and explaining research productivity. Higher Education 28(2), 207-226.

Rhoades, G., Kiyama, J.M., McCormick, R., Quiroz, M. (2008). Local Cosmopolitans and Cosmopolitan Locals: New Models of Professionals in the Academy. The Review of Higher Education 31/2: 209-235.

Rostan, M., Ceravolo, F.A. i Metcalfe, S.A. (2014). The Internationalization of Research. W: F. Huang, M. Finkelstein i M. Rostan (red.), The Internationalization of the Academy. Changes, Realities and Prospects. Dordrecht: Springer: 119-144.

Rostan, M., Ceravolo, F.A. (2015). The internationalization of the academy: convergence and divergence across disciplines. European Review 23(S1): 38-54.

Rørstad, K. i Aksnes, D.W. (2015). Publication rate expressed by age, gender and academic position - A large-scale analysis of Norwegian academic staff. Journal of Informetrics 9, 317-333.

Santiago, R., Carvalho, T. i Cardoso, S. (2015). Portuguese Academics' Perceptions of Higher Education Institutions' Governance and Management: A Generational Perspective. Studies in Higher Education 40(8), 1471-1484.

Shin, J.C., Arimoto, A. i Cummings, W.K. (2014). Teaching and Research in Contemporary Higher Education. Systems, Activities and Rewards. Dordrecht: Springer.

Shin, J.C., Jung, J., Kim, Y. (2014). Teaching and Research of Korean Academics Across Career Stages. W: J.C. Shin, A. Arimoto, W.K. Cummings, U. Teichler (red.), Teaching and Research in Contemporary Higher Education. Systems, Activities and Rewards (ss. 177-197). Dordrecht: Springer.

Smeby, J.-Ch. i Gornitzka, Å. (2008). All Cosmopolitans Now? The Changing International Contacts of University Researchers. W: Å. Gornitzka i L. Langfeldt (red.), Borderless Knowledge. Understanding „New” Internationalisation of Research and Higher Education in Norway. Dordrecht: Springer. 37-50.

Sooryamoorthy, R. (2014). Publication productivity and collaboration of researchers in South Africa: new empirical evidence. Scientometrics 98: 531-545.

Spector, P.E. (1981). Research designs. London: Sage.

Stephan, P. (2012). How economics shapes science. Cambridge, MA: Harvard University Press. 
Stephan, P.E., Levin, S.G. (1992). Striking the mother lode in science: the importance of age, place, and time. New York: Oxford University Press.

Teichler, U. i Höhle, E.E. (red.). (2013). The Work Situation of the Academic Profession in Europe: Findings of a Survey in Twelve Countries. Dordrecht: Springer.

Teichler, U., Arimoto, A. i Cummings, W.K. (2013). The Changing Academic Profession. Major Findings of a Comparative Survey. Dordrecht: Springer.

Teodorescu, D. (2000). Correlates of faculty publication productivity: A cross-national analysis. Higher Education 39(2), 201-222.

Thelwall, M., Maflahi, N. (2019). Academic collaboration rates and citation associations vary substantially between countries and fields. arXiv:1910.00789.

Uhly, K.M., Visser, L.M., Zippel, K.M (2015). Gendered patterns in international research collaboration in academia. Studies in Higher Education 42(4): 760-782.

Urbanek, P. (2018). Reform of the Higher Education System in Poland from the Perspective of Agency Theory. European Journal of Higher Education. Publikacja online: 20 grudnia 2018, https://doi.org/10.1080/21568235.2018.1560344.

Vabø, A., Padilla-Gonzales, L.E., Waagene, E., Naess, T. (2014). Gender and Faculty Internationalization. W: F. Huang, M. Finkelstein i M. Rostan (red.), The Internationalization of the Academy. Changes, Realities and Prospects. Dordrecht: Springer: 183-206.

Vaus, D. de (2002). Surveys in Social Research. $5^{\text {th }}$ Edition. Routledge: Milton Park

Villanueva-Felez, A., Molas-Gallart, M. i Escribá-Esteve, A. (2013). Measuring Personal Networks and Their Relationship with Scientific Production. Minerva 51, 465-483.

Wagner, C.S. (2006). International collaboration in science and technology: promises and pitfalls. W: Science and Technology Policy for Development, Dialogues at the Interface, red. L. Box i R. Engelhard. London: Anthem Press.

Wagner, C.S. (2008). The New Invisible College. Science for Development. Washington DC: Brookings Institution Press.

Wagner, C.S. (2018). The Collaborative Era in Science. Governing the Network. Cham: Palgrave Macmillan.

Wagner, C.S, Leydesdorff, L. (2005). Network structure, self-organization, and the growth of international collaboration in science. Research Policy 34: 1608-1618.

Weert, E. de, Kaap, H. van der (2014). The Changing Balance of Teaching and Research in the Dutch Binary Higher Education System. W: J.C. Shin, A. Arimoto, W.K. Cummings, U. Teichler (red.), Teaching and Research in Contemporary Higher Education. Systems, Activities and Rewards (ss. 113-133). Dordrecht: Springer.

Wolszczak-Derlacz, J. i Parteka, A. (2010). Scientific Productivity of Public Higher Education Institutions in Poland. A Comparative Bibliometric Analysis. Warsaw: Ernst and Young. Ziman, J. (1991). Academic science as a system of markets. Higher Education Quarterly 45(1), 41-61. Zippel, K. (2017). Women in Global Science. Stanford: Stanford University Press.

Zuckerman, H. (1970). Stratification in American science. Sociological Inquiry 40(2), 235-257. 


\section{Załącznik}

Tabela 17. Różnice w średnim tygodniowym czasie pracy ze względu na rodzaj działalności akademickiej i klaster dyscyplin naukowych

\begin{tabular}{|c|c|c|c|c|c|c|c|c|}
\hline \multirow[t]{2}{*}{$\begin{array}{l}\text { Cluster of } \\
\text { academic } \\
\text { disciplines }\end{array}$} & \multirow[t]{2}{*}{$\begin{array}{l}\text { Academic } \\
\text { activity }\end{array}$} & \multicolumn{2}{|c|}{$\begin{array}{l}\text { Mean hours } \\
\text { per week } \\
\text { (annualized) }\end{array}$} & \multirow[t]{2}{*}{$\begin{array}{l}\text { T-sta- } \\
\text { tistics } \\
\text { value }\end{array}$} & \multirow[t]{2}{*}{ P-value } & \multirow{2}{*}{$\begin{array}{c}\text { Group with } \\
\text { a sig. larger } \\
\text { mean (INT } \\
\text { or LOC) }\end{array}$} & \multirow{2}{*}{$\begin{array}{c}\% \\
\text { Differ- } \\
\text { ence (INT } \\
\text { vs. LOC) }\end{array}$} & \multirow{2}{*}{$\begin{array}{c}\text { Hours dif- } \\
\text { ference per } \\
\text { week (INT } \\
\text { vs. LOC) }\end{array}$} \\
\hline & & INT & LOC & & & & & \\
\hline \multirow{6}{*}{ 空 } & Teaching & 16,1 & 15,2 & 1,063 & 0,289 & - & 6,1 & 0,9 \\
\hline & Research & 23,4 & 18,6 & 3,978 & $<0,001$ & INT & 25,4 & 4,7 \\
\hline & Service & 5,5 & 4,4 & 1,713 & 0,088 & - & 26,1 & 1,1 \\
\hline & Administration & 5,5 & 5,7 & $-0,277$ & 0,782 & - & $-2,9$ & $-0,2$ \\
\hline & Other & 4,9 & 4,9 & 0,012 & 0,991 & - & 0,1 & 0,0 \\
\hline & Total hours & 49,6 & 43,7 & 2,963 & 0,003 & INT & 13,4 & 5,9 \\
\hline \multirow{6}{*}{ ర్ల } & Teaching & 16,8 & 17,4 & $-0,399$ & 0,691 & - & $-3,2$ & $-0,6$ \\
\hline & Research & 22,4 & 13,0 & 5,625 & $<0,001$ & INT & 72,5 & 9,4 \\
\hline & Service & 8,3 & 5,6 & 1,787 & 0,077 & - & 48,0 & 2,7 \\
\hline & Administration & 7,1 & 5,6 & 1,657 & 0,100 & - & 27,5 & 1,5 \\
\hline & Other & 5,1 & 5,3 & $-0,100$ & 0,920 & - & $-2,2$ & $-0,1$ \\
\hline & Total hours & 53,3 & 41,9 & 3,180 & 0,002 & INT & 27,2 & 11,4 \\
\hline \multirow{6}{*}{ 疍 } & Teaching & 12,5 & 14,2 & $-1,163$ & 0,247 & - & $-12,3$ & $-1,7$ \\
\hline & Research & 25,6 & 17,0 & 2,922 & 0,004 & INT & 50,3 & 8,6 \\
\hline & Service & 4,1 & 4,9 & $-0,556$ & 0,580 & - & $-15,4$ & $-0,8$ \\
\hline & Administration & 6,4 & 5,7 & 0,473 & 0,638 & - & 12,0 & 0,7 \\
\hline & Other & 4,5 & 4,1 & 0,505 & 0,615 & - & 11,4 & 0,5 \\
\hline & Total hours & 47,8 & 41,8 & 1,672 & 0,097 & - & 14,5 & 6,1 \\
\hline \multirow{6}{*}{ 公 } & Teaching & 14,2 & 16,8 & $-2,557$ & 0,011 & LOC & $-15,4$ & $-2,6$ \\
\hline & Research & 24,0 & 19,7 & 3,202 & 0,002 & INT & 21,9 & 4,3 \\
\hline & Service & 4,4 & 4,0 & 0,667 & 0,505 & - & 9,6 & 0,4 \\
\hline & Administration & 7,7 & 6,0 & 2,247 & 0,026 & INT & 29,0 & 1,7 \\
\hline & Other & 5,4 & 4,5 & 1,103 & 0,272 & - & 19,9 & 0,9 \\
\hline & Total hours & 49,3 & 46,3 & 1,446 & 0,149 & - & 6,5 & 3,0 \\
\hline \multirow{6}{*}{ 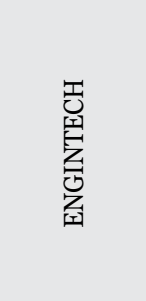 } & Teaching & 13,8 & 15,2 & $-1,897$ & 0,059 & - & $-9,5$ & $-1,4$ \\
\hline & Research & 19,0 & 17,3 & 1,475 & 0,141 & - & 9,7 & 1,7 \\
\hline & Service & 5,7 & 5,4 & 0,464 & 0,643 & - & 5,0 & 0,3 \\
\hline & Administration & 6,3 & 5,3 & 1,968 & 0,050 & - & 17,8 & 1,0 \\
\hline & Other & 5,8 & 5,8 & $-0,005$ & 0,996 & - & $-0,1$ & 0,0 \\
\hline & Total hours & 47,4 & 44,9 & 1,429 & 0,154 & - & 5,6 & 2,5 \\
\hline
\end{tabular}




\begin{tabular}{|c|c|c|c|c|c|c|c|c|}
\hline \multirow{2}{*}{$\begin{array}{l}\text { Cluster of } \\
\text { academic } \\
\text { disciplines }\end{array}$} & \multirow[t]{2}{*}{$\begin{array}{l}\text { Academic } \\
\text { activity }\end{array}$} & \multicolumn{2}{|c|}{$\begin{array}{l}\text { Mean hours } \\
\text { per week } \\
\text { (annualized) }\end{array}$} & \multirow{2}{*}{$\begin{array}{l}\text { T-sta- } \\
\text { tistics } \\
\text { value }\end{array}$} & \multirow{2}{*}{ P-value } & \multirow{2}{*}{$\begin{array}{c}\text { Group with } \\
\text { a sig. larger } \\
\text { mean (INT } \\
\text { or LOC) }\end{array}$} & \multirow{2}{*}{$\begin{array}{c}\% \\
\text { Differ- } \\
\text { ence (INT } \\
\text { vs. } \text { LOC) }\end{array}$} & \multirow{2}{*}{$\begin{array}{c}\text { Hours dif- } \\
\text { ference per } \\
\text { week (INT } \\
\text { vs. LOC) }\end{array}$} \\
\hline & & INT & LOC & & & & & \\
\hline \multirow{6}{*}{$\begin{array}{l}\text { 屿 } \\
\text { 导 } \\
\text { 总 }\end{array}$} & Teaching & 15,7 & 19,4 & $-1,707$ & 0,091 & - & $-19,2$ & $-3,7$ \\
\hline & Research & 21,0 & 17,8 & 1,665 & 0,099 & - & 17,8 & 3,2 \\
\hline & Service & 4,6 & 5,0 & $-0,369$ & 0,713 & - & $-8,0$ & $-0,4$ \\
\hline & Administration & 6,3 & 5,9 & 0,423 & 0,674 & - & 7,8 & 0,5 \\
\hline & Other & 5,8 & 6,3 & $-0,349$ & 0,728 & - & $-7,9$ & $-0,5$ \\
\hline & Total hours & 49,8 & 51,3 & $-0,412$ & 0,682 & - & $-3,1$ & $-1,6$ \\
\hline \multirow{6}{*}{ 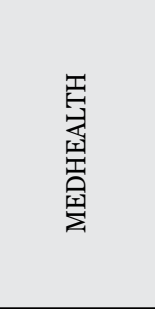 } & Teaching & 16,0 & 14,7 & 0,973 & 0,332 & - & 8,9 & 1,3 \\
\hline & Research & 19,9 & 14,3 & 3,157 & 0,002 & INT & 39,3 & 5,6 \\
\hline & Service & 7,2 & 8,8 & $-1,046$ & 0,297 & - & $-18,6$ & $-1,6$ \\
\hline & Administration & 7,7 & 5,3 & 2,914 & 0,004 & INT & 45,7 & 2,4 \\
\hline & Other & 5,7 & 5,5 & 0,182 & 0,856 & - & 3,2 & 0,2 \\
\hline & Total hours & 49,0 & 43,8 & 1,726 & 0,086 & - & 11,9 & 5,2 \\
\hline \multirow{6}{*}{ 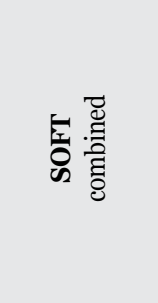 } & Teaching & 16,3 & 15,9 & 0,491 & 0,624 & - & 2,3 & 0,4 \\
\hline & Research & 23,1 & 16,7 & 6,557 & $<0,001$ & INT & 38,8 & 6,5 \\
\hline & Service & 6,3 & 4,8 & 2,206 & 0,028 & INT & 30,1 & 1,4 \\
\hline & Administration & 6,0 & 5,6 & 0,613 & 0,540 & - & 5,5 & 0,3 \\
\hline & Other & 5,0 & 5,0 & $-0,101$ & 0,920 & - & $-1,1$ & $-0,1$ \\
\hline & Total hours & 50,6 & 43,1 & 4,275 & $<0,001$ & INT & 17,4 & 7,5 \\
\hline \multirow{6}{*}{ 范蒫 } & Teaching & 14,2 & 16,0 & $-3,619$ & $<0,001$ & LOC & $-11,7$ & $-1,9$ \\
\hline & Research & 22,0 & 17,3 & 6,610 & $<0,001$ & INT & 27,0 & 4,7 \\
\hline & Service & 5,2 & 5,8 & $-1,499$ & 0,134 & - & $-10,8$ & $-0,6$ \\
\hline & Administration & 6,9 & 5,6 & 3,993 & $<0,001$ & INT & 24,6 & 1,4 \\
\hline & Other & 5,4 & 5,4 & $-0,008$ & 0,994 & - & $-0,1$ & 0,0 \\
\hline & Total hours & 48,5 & 45,8 & 2,481 & 0,013 & INT & 5,9 & 2,7 \\
\hline
\end{tabular}

Objaśnienie: Wyniki testu $t$ dla równości średnich, internacjonaliści (INT) i miejscowi (LOC). Pytanie B1: „Biorąc pod uwagę całą swoją aktywność zawodową, proszę wskazać, ile godzin w ciągu tygodnia przeznacza Pan(i) na każde z wymienionych poniżej zajęć w bieżącym roku akademickim" (średnia roczna: $60 \%$ w okresie prowadzenia zajęć i 40\%, kiedy zajęcia nie są prowadzone)? 


\title{
Internationalists and Locals - International Research Collaboration in Poland at the Micro-level of Individual Scientists
}

\begin{abstract}
The paper contrasts „internationalists” and „locals” (i.e. researchers who are international and local in their research): the former are researchers involved in international research cooperation and the latter are not. As a clearly defined group of Polish scientists (51.4\%), internationalists are a separate type. Dehermetisation of the Polish science system puts locals in a radically more difficult situation. The processes we call „internationalization cumulative advantage” and „internationalization cumulative disadvantage" occur simultaneously, dividing the scientific community in terms of prestige, recognition and access to competitive research funding. Internationalisation in research is a powerful stratifying force, not only for institutions (causing their vertical diversification) but also for their departments (leading to horizontal segmentation). Highly internationalised institutions, departments, research groups and individual researchers are therefore emerging. Nine working hypotheses have been tested concerning gender, age and academic position, national cooperation, research productivity, distribution of working time, orientation towards academic roles, predictors of being internationalist and type of research productivity. Internationalists are mainly men and older scientists with longer academic experience and higher degrees. In all clusters of academic disciplines, internationalists generate more than $90 \%$ of publications produced as part of international cooperation: the lack of international cooperation in practice means the lack of internationally co-authored publications. Internationalists are much more productive when it comes to international co-authored publications: they represent $2320 \%$ of local productivity for peer-reviewed articles and $1600 \%$ for their equivalents. Internationalists spend less time on teaching, more on research and more on administrative duties. In Poland, the majority of female researchers are local (55\%) and the majority of men are internationalists (56\%). Therefore, the advancement of women on the academic ladder based on purely scientific achievements is likely to be longer over time, and access to increasingly competitive individual funds for research is increasingly difficult. Our multidimensional analyses (logistical regression) have identified new predictors of engagement in international research collaboration. The results of our analyses based on an extensive survey ( $\mathrm{N}=3,704$ returned questionnaires) lead to conclusions about academic careers, productivity patterns and internationalisation of research.
\end{abstract}

KEYWORDS: international research collaboration, internationalization, global science, local science, Polish scientists, Polish academic profession

CYTOWANIE: Kwiek, M. (2019). Internacjonaliści i miejscowi - międzynarodowa współpraca badawcza w Polsce na mikropoziomie indywidualnych naukowców. Nauka i Szkolnictwo Wyższe. 1-2(53-54): 47-105. DOI: 10.14746/nisw.2019.1-2.2.

MAREK KWIEK - prof. dr hab., dyrektor Centrum Studiów nad Polityką Publiczną (od 2002) i kierownik katedry UNESCO Badań Instytucjonalnych i Polityki Szkolnictwa Wyższego (od 2012) na UAM w Poznaniu. 
Zajmuje się ilościowymi badaniami nauki, socjologią karier akademickich i badaniami nad szkolnictwem wyższym. Jego zainteresowania naukowe koncentrują się na teoriach międzynarodowej współpracy naukowej, produktywności badawczej, stratyfikacji w nauce i badaniu globalnych elit akademickich, łącząc międzynarodowe badania ankietowe i badania bibliometryczne. Opublikował ok. 200 prac, a jego najnowsza monografia to Changing European Academics: A Comparative Study of Social Stratification, Work Patterns and Research Productivity (Routledge 2019). Był kierownikiem w 25 międzynarodowych projektach badawczych i w ostatniej dekadzie dla swoich zespołów badawczych zdobył w formie grantów 8 mln PLN. Jest członkiem rady redakcyjnej Higher Education Quarterly, European Educational Research Journal, British Educational Research Journal oraz European Journal of Higher Education, www.cpp.amu.edu.pl. E-mail: kwiekm@amu.edu.pl 